\title{
AINDA VALE A PENA LEGISLAR: AATUAÇÃO DOS AGENDA HOLDERS NO CONGRESSO BRASILEIRO
}

\author{
Rafael Silveira e Silva
}

\author{
Suely Mara Vaz Guimarães de Araújo
}

\begin{abstract}
RESUMO
O artigo analisa a estratégia de atuação de parlamentares que se dedicam e se destacam na articulação política na arena de produção de leis, denominados agenda holders. O objetivo é apresentar os marcos analíticos e o delineamento desse conceito no âmbito dos Estudos Legislativos e propor estratégias metodológicas para a observação e análise desses agentes políticos no Congresso Nacional. Foram empregadas três abordagens diferenciadas, cada qual formulada no sentido de selecionar casos em que os parlamentares foram protagonistas nos processos legislativos. Analisaram-se vários exemplos, entre os anos 2007 e 2011, que envolveram o fenômeno da apropriação da agenda do poder Legislativo, os processos legislativos realizados por meio das comissões especiais na Câmara dos Deputados e a participação dos relatores na tramitação das medidas provisórias. Tais abordagens metodológicas foram bem sucedidas, resultando em interessantes observações acerca dos requisitos compartilhados para a atuação do parlamentar como agenda holder, tais como sua experiência pregressa e possiveis especializações, a seniority no Congresso e sua capacidade de negociação. As análises também permitiram observar uma ligação consistente entre assumir a condição de agenda holder e sobrevivência política, bem como as diferenças de atuação entre deputados e senadores. Ademais, foi possível verificar a existência de parlamentares que podem assumir, de acordo com algumas circunstâncias, o papel de anti-agenda holders. Compreende-se que estudos sobre o comportamento dos agenda holders podem enriquecer as análises que abordam as ações do poder Legislativo, enfatizando, ainda, a necessidade de uma visão mais apurada sobre a dinâmica da relação entre o Congresso e o poder Executivo. Além disso, explora-se por outro prisma a construção de carreiras políticas, inserindo grau de relevância nas ações dos parlamentares no processo legislativo, a despeito de todas as dificuldades e limitações. Desse modo, também se resgata o lugar dos parlamentares na moldagem da agenda legislativa em senso estrito e na atividade primária de formulação das leis.
\end{abstract}

PALAVRAS-CHAVE: agenda holder; parlamentares; carreira política; Congresso; metodologia.

\section{INTRODUÇÃO ${ }^{1}$}

Da forma que foi desenhado, o sistema político brasileiro assegura um controle da produção legal de forma quase imperial ao poder Executivo. Verifica-se que pelo menos $80 \%$ das leis federais são oriundas de proposições legislativas de autoria formal do Presidente da República, considerando projetos de lei complementar, projetos de lei ordinária e medidas provisórias (PEREIRA \& MUELLER, 2000, p. 65; FIGUEIREDO \& LIMONGI, 2001, p. 50-51; AMORIM NETO \& SANTOS, 2003, p. 664; PEREIRA, POWER \& RENNÓ, 2005, p. 403; AMORIM NETO, 2006, p.

\footnotetext{
1 Versão preliminar deste trabalho foi apresentada no I Seminário Internacional Instituições, Comportamento Político e Geografia do Voto (Geovoto), realizado em Brasília, em maio de 2012, e no VI Congreso Latinoamericano de Ciencia Política de Alacip, realizado em Quito, em junho de 2012. Os autores agradecem os comentários feitos pelos professores Marcelo Leiras, Lucio Rennó, Denilson Coêlho e Alejandro Bonvecchi, bem como aos pareceristas anônimos da Revista de Sociologia e Política.
}

130). Em contraposição, apenas $1,9 \%$ das iniciativas dos parlamentares brasileiros foram convertidas em lei durante o período de 1990 a 2006 (GARCÍA MONTERO, 2009).

Talvez o país que mais se assemelhe ao Brasil seja a Argentina, onde as taxas de aprovação dos projetos de iniciativa dos parlamentares alcançou pouco mais de 4,2\%, entre 1984 e 2007 . No entanto, ao contrário do que se pode esperar, os legislativos da maioria dos países latino-americanos conseguem converter seus próprios projetos em lei, na média, a taxas superiores a $20 \%$, mesmo contando com poderes executivos fortes na área legislativa $(\text { idem })^{2}$.

\footnotetext{
2 De certa forma, quase todos esses países possuem presidentes fortes, mas a configuração institucional entre os poderes de cada república determinam resultados legislativos variados. Basta comparar o exemplo do Chile, cuja presidência é tão forte como a brasileira em termos de capacidade legislativa, porém apresenta perfil bem diferenciado quanto à participação dos projetos de lei dos parlamentares nos respectivos arcabouços legais.
} 
No Brasil, esse quadro de preponderância do Executivo sobre o Legislativo na esfera legiferante tem sido explicado, principalmente, pelas regras presentes na própria Constituição Federal, que asseguram ao Presidente da República ( $i$ ) a iniciativa exclusiva na apresentação das proposições legislativas que disponham sobre a administração pública federal em senso estrito ou sobre a questão orçamentária; (ii) a prerrogativa da adoção das medidas provisórias e (iii) o poder de solicitar urgência da tramitação dos projetos de lei complementar ou ordinária de sua autoria ${ }^{3}$, assim como pela capacidade de centralização do processo decisório no Congresso Nacional nos líderes dos partidos políticos que integram a base política do governo. O poder Executivo, na prática, em ação articulada com os líderes, seria o responsável pela definição da agenda legislativa.

A leitura mais frequente é a de um Congresso Nacional integrado por parlamentares passivos, que "carimbariam" as propostas encaminhadas pelo Presidente da República e chanceladas pelos líderes da base aliada. Os deputados federais e senadores, em grande medida, delegariam a tarefa de legislar. Essa noção ainda é reforçada quando se considera que o Executivo "detém a prerrogativa de iniciar a legislação de maior interesse e, dessa forma, pode explorar estrategicamente esse direito" (LIMONGI \& FIGUEIREDO, 2009, p. 77), indicando que o raio de atuação do parlamentar é limitado por apenas agir após o governo ter apresentado sua proposta. O elevado índice de sucesso das proposições legislativas apresentadas pelo Executivo costuma ser colocado como respaldo empírico dessa leitura.

Nesse quadro, a atuação dos parlamentares na arena legislativa, entendida aqui como a arena da produção de leis ${ }^{4}$, tende a ser considerada pouco proveitosa politicamente, dada a difícil obtenção de frutos gerados diretamente no campo eleitoral. Para alguns, importaria mais que os parlamentares mantivessem relações de cordialidade com um Executivo que tem autoridade final sobre a alocação de verbas para o atendimento das demandas das bases eleitorais, do que propriamente legislar (AMES, 2003) $)^{5}$. Para outros, o que realmente

\footnotetext{
3 A fundamentação desses mecanismos institucionais está nos arts. $61, \S 1^{\circ}, 62,63,64, \S 1^{\circ}, 165$ e 166 da Constituição Federal.

4 Consideramos como "arena orçamentária" toda atividade que envolve a aprovação e a execução orçamentária.

5 O poder de emenda aos projetos das leis orçamentárias restringe-se às verbas alocadas para investimento e não podem envolver gastos destinados a pessoal e serviço da dívida (art. 166 da Constituição Federal). Há limitações adicionais quanto ao número e ao valor das emendas parlamentares impostas por regras internas do Congresso Nacional. De forma geral, são regi-
}

conta é assegurar a coordenação necessária para a aprovação da "agenda da maioria". Esta seria espelhada por meio das propostas do Executivo e representaria a vontade dos partidos membros da coalizão governamental (LIMONGI \& FIGUEIREDO, 2009).

Mesmo que a atividade parlamentar na arena legislativa enfrente constrangimentos institucionais, defendemos que a análise mais detida sobre os trabalhos do Parlamento pode lançar novas luzes sobre a interação Legislativo-Executivo no que concerne à estruturação da agenda governamental e à formulação das bases legais das políticas públicas. Não se pode negligenciar que há parlamentares, de diferentes vínculos partidários, que assumem papel relevante em vários processos que tramitam no Congresso Nacional, destacando-se na articulação sobre as matérias em debate, bem como na tradução dessa articulação em textos que garantem consistência política e técnica às leis produzidas. Esses parlamentares seriam os agenda holders (SILVA\& ARAÚJO, 2010; ARAÚJO \& SILVA, 2012).

Neste artigo, buscaremos delinear o conceito e as estratégias metodológicas para mapear a atuação desses parlamentares. As questões principais são (i) estudar como e em que condições um parlamentar se torna um agenda holder, proporcionando uma visão mais detalhada da relação entre os Poderes Legislativo e Executivo; e (ii) identificar o que necessita ser analisado no processo legislativo movido pelos parlamentares para a construção das próprias carreiras políticas, a despeito de todas as dificuldades e limitações. Desse modo, também se resgata o lugar dos parlamentares na construção da agenda legislativa e na atividade primária de formulação das leis.

Consideramos que a realidade do Congresso Nacional é complexa e que as variáveis geralmente utilizadas nos estudos legislativos sobre o caso brasileiro não conseguem captar todas as diferentes facetas do processo que perpassa a elaboração de leis (ARAÚJO \& SILVA, 2012). Para que se alcance maior robustez nas análises sobre o Parlamento, exige-se um aprofundamento sobre o grau de repercussão da atuação do próprio parlamentar, que ultrapasse a leitura de atores agindo somente segundo o esquema dicotômico de apoio ou combate às propostas do Executivo. Nesse esforço, parece indicada a combinação de estratégias metodológicas qualitativas

mental e politicamente priorizadas as emendas coletivas (LIMONGI \& FIGUEIREDO, 2009, p. 81). Se individualmente considerados, os membros do Legislativo estão sujeitos na arena orçamentária a limitações ainda mais fortes do que na arena legislativa. 
e quantitativas. Desse modo, além de aprofundarmos o conceito, pretendemos indicar abordagens distintas para a observação da atuação dos agenda holders, as quais devem ser lidas como complementares e não exaustivas.

\section{CAMINHOS PARAAATUAÇÃO PARLAMENTAR}

Para avaliar-se a capacidade legislativa dos parlamentares, deve-se adotar como universo de comparação o conjunto de matérias cujo poder de iniciativa é compartilhado entre o Executivo e Legislativo $^{6}$, bem como se faz necessário levar em conta as alterações realizadas pelos parlamentares nas proposições legislativas apresentadas pelo Presidente da República, no curso do processo legislativo. Ainda não há banco de dados amplo disponível sobre essas alterações. No entanto, impõe-se compreender que a iniciativa das proposições legislativas não assegura, por si só, que o produto final dos processos reflita as preferências do Executivo. Não se podem gerar conclusões sobre a arena legislativa apenas em face das restrições institucionais que moldam seu funcionamento, sem estudar também a sua dinâmica interna na prática e respectivos outputs.

No trâmite de projetos de lei, em grande parte dos processos gera-se substitutivo ${ }^{7}$, ou mesmo vários substitutivos. No caso das medidas provisórias, qualquer alteração, de pequena ou grande monta, impõe a formulação de projeto de lei de conversão ${ }^{8}$. Sem entrar no mérito das alterações, tomando-se para análise, por exemplo, as leis sancionadas no ano de 2010, originadas de medidas provisórias, verificam-se casos concretos de ampla participação do Congresso na configuração final da lei, especialmente nas matérias não inclusas na esfera da iniciativa privativa do Presidente da República. Ao mesmo tempo, constatase que, nas propostas relativas à gestão da máquina governamental, os parlamentares tendem a não fazer acréscimos ou mudanças significativas nas propostas do Executivo (idem, p. 65-66). Há, também, muitos casos em que as proposições encaminhadas pelo Presidente da República são apensadas a propostas similares de autoria de deputados ou senadores,

\footnotetext{
6 Cerca de $40 \%$ das leis federais produzidas referem-se a atos normativos pontuais, de iniciativa exclusiva do Presidente da República por força de previsão da Constituição Federal, referentes a créditos orçamentários específicos. Cf. Silva e Araújo (2013).

7 Formulam-se substitutivos quando as propostas de modificação demandam muitas emendas pontuais e nas situações em que se intenta unificar em um único texto diferentes propostas.

8 Ver art. 62, § 12, da Constituição Federal.
}

previamente em trâmite no Congresso Nacional, assim como o fenômeno da apropriação, no qual projetos de lei ou medidas provisórias do governo são inspirados em propostas dos parlamentares previamente apresentadas (SILVA \& ARAÚJO, 2010; ARAÚJO \& SILVA, 2012).

Em face disso, no que tange à atuação parlamentar, deve-se ter cautela ao julgar resultados pelo quantitativo de leis e sua autoria formal. É necessária maior atenção para os processos legislativos e suas diferenças, bem como para os resultados de cada uma de suas etapas.

Como destacado de início, mesmo havendo diferentes leituras sobre os mecanismos que norteiam a atuação parlamentar em nosso presidencialismo de coalizão, predomina o entendimento de que o forte poder legiferante do Presidente da República e a centralização do processo decisório nas mãos dos líderes partidários no Congresso Nacional tendem a tornar inócua a ação independente e individual dos deputados e senadores na produção de leis (ARAÚJO \& SILVA, 2013). O curso de ação racional seria a atuação por intermédio dos partidos políticos, vistos como veículos praticamente obrigatórios para que os políticos tenham influência sobre as políticas públicas e, dessa forma, pleiteiem mandatos junto ao eleitorado (FIGUEIREDO \& LIMONGI, 2002).

Embora coloque em evidência que o aumento das prerrogativas do Executivo retira do Legislativo capacidade de efetivamente gerar contribuções para a formulação das políticas públicas, Santos (1997) admite que os parlamentares possuem uma gama variada de estratégias para obter e defender seus mandatos. Dessa forma, mesmo que grande parte das matérias que ganham destaque na pauta política sejam mediadas por um Presidente da República poderoso e por partidos fortes na arena legislativa, o referido autor não nega que pode haver oportunidades para ações parlamentares independentes e individuais.

Entendemos que não pode ser desprezada a relevância do investimento dos parlamentares na apresentação de projetos de lei, a despeito das inúmeras barreiras estabelecidas por nosso sistema político para a aprovação dessas propostas. Devemos buscar tal relevância justamente na premissa de que o político, por razões individuais ou ideológicas, tem interesse em manter-se no poder, visando a reeleição ou a incrementar sua carreira política por diversos meios, entre os quais formular e aprimorar textos legais.

Podemos traduzir essa atuação como um investimento em termos de capital político, especialmente quando há um reconhecimento da legitimidade de determinado indivíduo para agir na política (MIGUEL, 2003). A lógica é simples: quanto 
maior o capital político, maior legitimidade e maior desenvoltura para atuar politicamente, permitindo a formação de redes partidárias e extrapartidárias necessárias à busca e manutenção do mandato eleitoral.

Os atores procuram manter a capacidade de transitarem entre situações políticas distintas ou entre os partidos políticos, sem perderem suas posições de destaque. Nessa perspectiva, ganha relevância o reconhecimento do significado de sua participação em processos que têm potencial para gerarem lei, atendendo à demanda de seus eleitores. Do ponto de vista do parlamentar, o reconhecimento de sua atuação na aprovação de uma proposição legislativa, seja como autor, seja como relator, coloca-o potencialmente em uma posição de destaque diante não somente dos eleitores, mas também de seu partido político, da coalizão de que faz parte (governista ou ou oposição) e de seu grupo temático, assim considerados as frentes parlamentares suprapartidárias organizadas em prol de temas específicos ou os grupos de pressão que tenham vínculos com o parlamentar (ARAÚJO \& SILVA, 2013).

Quando um parlamentar dedica-se a um ou mais projetos de lei, seja como autor, seja como relator, ele realiza um investimento em seu capital político, que poderá ter, direta ou indiretamente, repercussões no âmbito da conexão eleitoral. Com uma atuação eficaz nessa linha, ele poderá ter ganhos políticos, tais como passar a ser visto como interlocutor importante em determinado tema ou como um parlamentar "especialista", ganhar expressão dentro do seu partido ou grupo partidário e, em decorrência, ser nomeado para cargos no Legislativo, como a presidência de comissões ou postos nas mesas diretoras. Dependendo da questão em tela, também poderá chamar a atenção do Executivo, obtendo acesso a importantes recursos na esfera daquele poder. Mesmo que se entenda que o que realmente conta é a agenda da maioria (LIMONGI \& FIGUEIREDO, 2009), deve ser percebido que esse destaque poderá implicar a possibilidade de o parlamentar ser chamado a participar concretamente do processo que delineia tal agenda.

Dessa forma, torna-se relevante fazer parte dos processos de discussão e tomada de decisão sobre os projetos de lei e outras proposições legislativas, não apenas no âmbito dos plenários das casas legislativas, mas também nas comissões permanentes e temporárias, especialmente quando o parlamentar está à frente de determinado processo, centralizando as negociações em torno do futuro texto legal e servindo de ponto de referência para o governo e os grupos organizados. Ou seja, aquele que está cuidando e orientando as discussões das matérias em tramitação, enfim, que consegue atuar como agenda holder.

\section{AGENDA HOLDER: MARCOS ANALÍTICOS}

A primeira questão de pesquisa que se coloca é saber diferenciar quem são os agenda holders e como eles atuam, evitando distinções maniqueístas e considerando a valorização do papel do Legislativo em sua função primária de formulação dos textos legais. Não se objetiva colocar em dúvida a relevância do Executivo na produção das leis no país, mas sim trazer à tona elementos para que se compreendam as contribuições dos parlamentares, que não se resumem a aprovar propostas acordadas entre o governo e os líderes partidários. Outra importante aspecto a ser enfrentado é como estudar a atuação dos agenda holders.

Essas questões configuram verdadeiros desafios, na medida em que a literatura não trata desse tema, a não ser quando, em estudos de casos, realizam-se rastreamentos de processos que permitem observar com detalhes as ações de alguns parlamentares. Ainda assim, nem sempre, nesses estudos de caso, conseguese realmente aferir o grau de participação dos atores políticos na esfera legislativa.

Abordaremos essas duas questões de forma integrada neste trabalho, esperando despertar interesse de outros pesquisadores para o conceito e a atuação dos agenda holders, para que se possam ampliar as pesquisas sobre o assunto.

Considera-se que um parlamentar atua como agenda holder quando, em determinadas matérias, " [...] centraliza articulações políticas entre os demais parlamentares, o Poder Executivo e representantes do empresariado e da sociedade civil organizada, em atuação que tende a ter repercussões relevantes nos textos legais produzidos" (ARAÚJO \& SILVA, 2013, p. 292).

Um parlamentar que atua como agenda holder não o faz apenas quando é relator. Pode ser o próprio autor que acompanha a tramitação de sua proposição, participando ativamente das discussões e negociações, servindo de ponte ao(s) relator(es) ao longo do processo. Pode ser, também, o parlamentar no exercício de função similar à relatoria, como a coordenação de um grupo de trabalho ou mesmo o presidente de uma comissão, seja quando avoca a si a relatoria de uma matéria, seja quando contribui ativamente na condução das discussões.

Fazendo algumas pontes com a literatura, julgamos que a figura do agenda holder supera a perspectiva da função de advisor ad hoc dos parlamentares, relacionada aos relatores por Santos e Almeida (2005), uma vez que o agenda holder não apenas especializase sobre determinada questão, contribuindo com 
elementos informacionais, mas atrai para si parte importante das negociações políticas. Ele pode, também, exercer a função de policy broker junto aos eleitorado e aos grupos interessados, reduzindo o grau de conflito entre eles e contribuindo para que se alcancem outputs mais consensuais nos processos de tomada de decisão relativos às bases legais das políticas públicas (SABATIER \& JENKINS-SMITH, 1993; 1999).

Além disso, quando falamos de agenda holders estamos vinculando a atuação do parlamentar ao mérito das propostas legislativas, bem como à viabilização da proposta para ser discutida e votada nas várias instâncias de cada casa legislativa. Isso pode remeternos, eventualmente, à figura do agenda setter. No entanto, aqui temos de diferenciá-lo do agenda holder, na medida em que o primeiro exerce uma função formal e específica que o capacita a inserir propostas nas pautas de discussão e votação de determinada arena decisória. Isso, por si só, não garante que ele seja um agenda holder, a não ser que também tenha influência nas discussões e nas articulações que favoreçam o trâmite legislativo.

Deve ser dito que a condição de agenda holder não determina que o parlamentar seja neutro, embora do ponto de vista democrático e da qualidade legislativa, agir dialogando e interagindo com as partes interessadas em um projeto de lei, buscando solução de equilíbrio, pareça ser a atitude mais desejável para um parlamentar com essa condição. O que se quer dizer é que, conduzir uma agenda, ainda que com viés, atraindo a atenção das partes envolvidas, entre elas o governo, e, principalmente, gerando produtos que podem envolver desde a produção de um parecer até a construção de um texto que venha a se tornar lei, já torna o parlamentar um forte candidato a agenda holder.

FIGURA 1 - NÍVEIS DE ATUAÇÃO DOS AGENDA HOLDERS

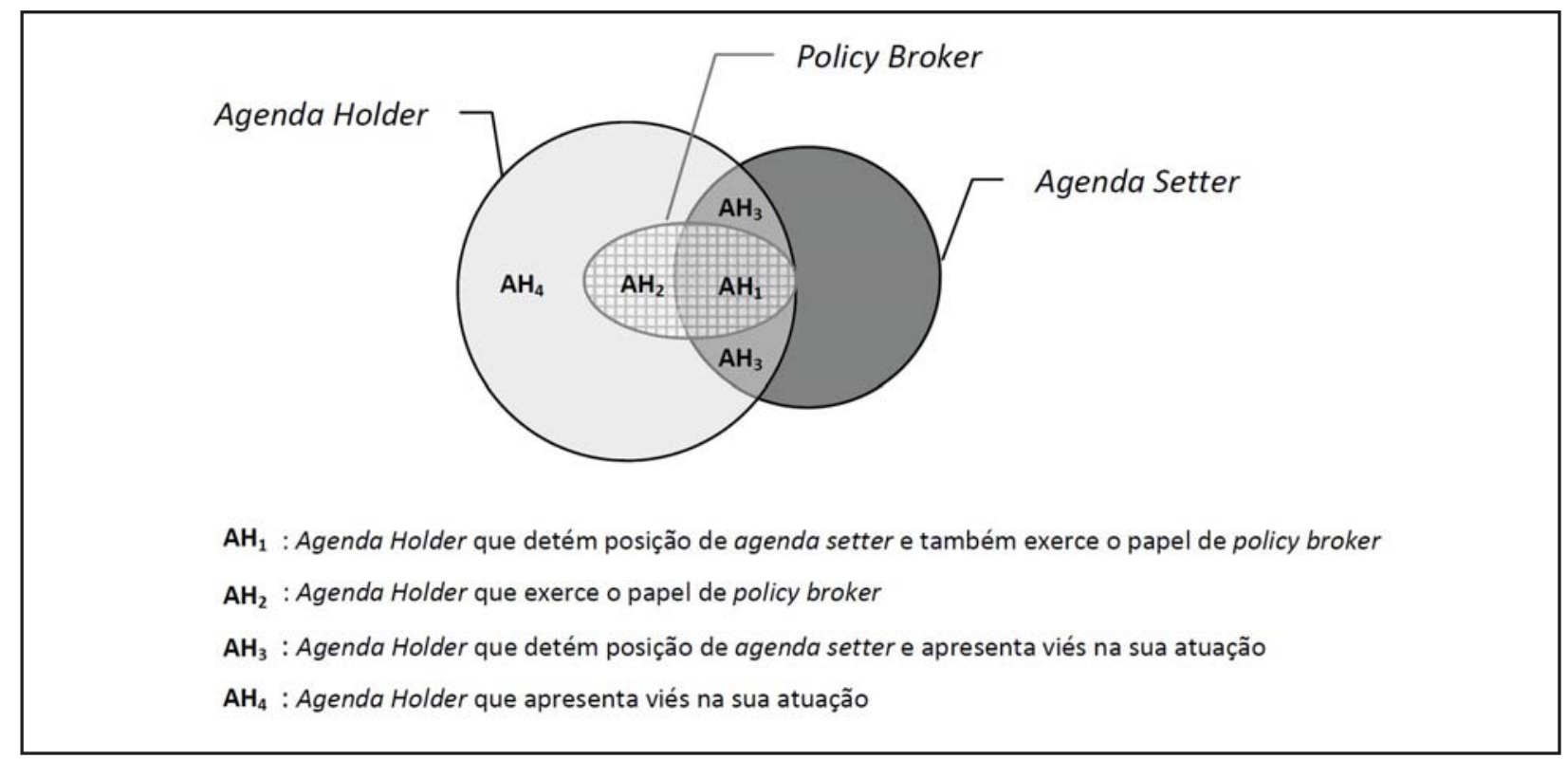

FONTE: Os autores.

De acordo com a Figura 1, o agenda holder que ocupa a posição " $\mathrm{AH}_{1}$ " é o que se vale da vantagem de ser agenda setter para atuar ativamente sobre certa matéria e, concomitantemente, promove uma aproximação entre as partes interessadas, de maneira a conduzir a matéria da maneira consensual possível. Desse modo, podemos visualizar alguns graus de atuação como agenda holder conforme a posição institucional (agenda setter) e a forma de atuação entre uma posição mais conciliadora (policy broker) e uma posição mais favorável a algumas partes envolvidas (viés). Dada a quantidade restrita de posições de agenda setting, deveremos encontrar atuações mais frequentes nos níveis " $\mathrm{AH}_{2}$ " e " $\mathrm{AH}_{4}$ ".

Cabe então verificar quais estratégias metodológicas são adequadas para mapear os agenda holders. Primeiramente, poderíamos observar o conteúdo veiculado pelos meios de comunicação como a forma mais rápida para verificar a que os parlamentares se dedicam. É fácil compreender essa abordagem, tendo em vista que, no fundo, todos os políticos querem atrair a cobertura da mídia para si, além de a maior parte deles construírem estratégicas específicas para isso. Miguel (2003) é um dos autores que procura observar a mídia como fonte de obtenção de capital 
político, assumindo que a visibilidade oferecida pelos meios de comunicação é condição importante para o reconhecimento público. Desse modo, a mídia interferiria na estrutura da carreira política por meio da produção de capital político, conformando "atalhos" que permitiriam a postulação de cargos mais elevados e acesso mais efetivo às estruturas de poder.

A título de exemplo, tomamos dois parlamentares de partidos com linhas ideológicas e de atuação bem diferenciadas e que podemos considerar, pelo conceito por nós adotado, como agenda holders consolidados. Esses dois casos evidenciaram-se nas primeiras investidas de cunho exploratório sobre o tema (SILVA \& ARAÚJO, 2010), mesmo antes de o conceito de agenda holder avançar com contornos mais nítidos.

Constitui fato público e notório que o Senador Paulo Paim (PT-RS) é um parlamentar que atrai demandas políticas em torno dos temas afetos à questão trabalhista e previdenciária. Sindicatos, associações patronais e a imprensa tratam-no como um dos responsáveis pelo assunto no Congresso Nacional. "O Executivo sabe que esse parlamentar estará envolvido nas negociações em relação a esses temas, com posicionamento crítico mesmo no período em que seu partido esteja no poder" (ARAÚJO \& SILVA, 2013, p. 296). Outro exemplo ilustrativo é o da Senadora Kátia Abreu (PSD-TO). A parlamentar, que possui grande influência no âmbito da Confederação Nacional da Agricultura e Pecuária (CNA), tem atuação de destaque nas negociações sobre a pauta política relacionada, direta ou indiretamente, à agropecuária. A chamada bancada ruralista é historicamente numerosa e poderosa, mas seus membros não têm o papel de articulação da senadora. O Executivo e a imprensa têm consciência disso.

Embora a importância da mídia seja inquestionável, sabemos que a seleção por parte de quem cobre as atividades parlamentares recai sobre o que mais chama a atenção do grande público. Esse aspecto é mais valorizado do que o cerne dos debates das centenas de assuntos que são debatidos no dia-a-dia do Congresso Nacional. A imprensa sabe, seja pela história, seja pela posição estratégica do congressista, a quem procurar. No entanto, não se pode desprezar que há um forte viés nessa seleção, especialmente nos temas abordados. $\mathrm{Na}$ maioria dos casos, o parlamentar que aparece na mídia, posicionando-se sobre determinada matéria, é um ator relevante do Congresso. Isso não quer dizer que esse parlamentar seja um agenda holder.

É importante entender que há parlamentares que atuam como agenda holder que não têm a especialização temática, nem a força de articulação, tão em evidência quanto nos exemplos do Senador
Paulo Paim e da Senadora Kátia Abreu. Por isso, percebemos a necessidade de adotar estratégias metodológicas alternativas e também complementares para estruturar as análises nesse âmbito, qualificandoas em termos de maior precisão acerca do processo legislativo e do papel exercido pelo parlamentar.

Julgamos que as abordagens para a observação da atuação dos agenda holders podem ser concretizadas por meio da análise temática, que se aprofunda no conteúdo dos debates que ocorrem no Legislativo, ou por meio dos mecanismos de centralização geralmente adotados para a tramitação de algumas proposições.

A análise temática exige um conhecimento detalhado dos assuntos tratados no Congresso Nacional, o que requer familiaridade com os atores envolvidos e com a forma que geralmente o Legislativo funciona. Um dos recortes metodológicos que podemos adotar para verificar a atuação dos agenda holders pelo tratamento temático é observar seus papéis nos processos de apropriação da agenda do Legislativo, nos quais também se pode observar a atuação do Presidente da República. Os casos aqui abordados relacionados a esse primeiro recorte já haviam sido trabalhados anteriormente, com olhar mais voltado para os detalhes da apropriação (SILVA \& ARAÚJO, 2010; ARAÚJO \& SILVA, 2013).

Pelos mecanismos de centralização, propomos, neste trabalho, dois caminhos adicionais que podem evidenciar os agenda holders: $(i)$ o processo legislativo realizado por meio das comissões especiais na Câmara dos Deputados e (ii) a participação dos relatores na tramitação das medidas provisórias. O recorte temporal do estudo empírico das comissões especiais e das medidas provisórias foi a 53ª Legislatura (2007-2011).

Na sequência, desenvolveremos cada uma dessas três trilhas metodológicas. Como já referido, as três alternativas são complementares, e não exaurem as possibilidades de outros caminhos para o estudo dos agenda holders.

\section{AGENDA HOLDERS E A APROPRIAÇÃO DA AGENDADO LEGISLATIVO ${ }^{9}$}

O fenômeno da apropriação da agenda é verificado quando projetos de lei ou medidas provisórias do governo são inspirados em propostas que tramitam no Parlamento. A apropriação pode assumir diferentes feições e graus, variando da simples abordagem nas proposições do Executivo de políticas que estavam anteriormente sendo tratadas pelo Congresso até a

\footnotetext{
9 Para uma visão sistematizada desta seção, recomendamos ver o Anexo I.
} 
adoção de cópias literais de dispositivos ou de proposições legislativas em trâmite. Com isso, também se contrapõe a noção de que as matérias de interesse do Executivo têm origem exclusivamente dos órgãos da administração pública (SILVA \& ARAÚJO, 2010). Excetuando-se as proposições caracterizadas como de iniciativa exclusiva do Presidente da República, constata-se que, no período de 1995 a 2010, 18,5\% das medidas provisórias e $40 \%$ dos projetos de lei do Executivo surgiram por meio da apropriação da agenda do Legislativo (ARAÚJO \& SILVA, 2012).

A condição de agenda holder pode alçar o parlamentar a um relacionamento especial com o poder Executivo, quando a matéria da qual está cuidando, ou a própria atuação do parlamentar, chama a atenção desse ator político poderoso. É nesse ponto que pode ocorrer a relação entre a figura do agenda holder e o fenômeno da apropriação da agenda: quanto mais bem articulada e desenvolvida a ideia (e o texto) da proposição dentro do Parlamento, maiores as chances de haver interesse direto e, consequentemente, de a proposição ser apropriada pelo Executivo.

As situações que envolvem apropriação da agenda, o agenda holder pode estar na condição de autor da proposição legislativa ou de relator que tenha produzido substitutivo que sofreu apropriação. Se esse ator político conseguir tirar proveito desse processo, ou seja, se conseguiu participar antes ou durante a tramitação das propostas do Executivo que resultaram da apropriação, ele poderá impulsionar sua carreira e suas chances de continuar compartilhando poder. Assim, há de se considerar que o fenômeno da apropriação pode trazer, também, uma oportunidade de aquisição de maiores recursos políticos para o parlamentar, ampliando as possibilidades de ele pleitear ou indicar cargos no Executivo, ou de ter mais acesso à aprovação e liberação de emendas orçamentárias (LEONI, PEREIRA \& RENNÓ, 2003; PEREIRA \& RENNÓ, 2007). Nessa leitura, o estudo do fenômeno da apropriação pode relacionar as proposições legislativas iniciadas pelos congressistas e carreiras políticas, com possibilidade de mútuo benefício para atores do Parlamento e do Executivo quando há aproximação de suas preferências (ARAÚJO \& SILVA, 2013).

Neste primeiro foco do estudo sobre os agenda holders foram selecionadas situações de apropriação que já se encontravam descritas por Silva e Araújo (2010), cujo trabalho abrangeu várias legislaturas, desde 1995. Essa opção deu-se em razão tanto de a apropriação tender a evidenciar a efetividade dos parlamentares na produção das leis, quanto do fato de os respectivos processos legislativos estarem com seu rastreamento previamente realizado. Trata-se apenas de uma amostra. Há um conjunto extenso de outros casos de apropriação que poderão ser estudados com o intuito de identificar e analisar a atuação de agenda holders.

Após releitura e análise cuidadosa de toda a documentação dos 20 casos de apropriação levantados por Silva e Araújo (idem), concluiu-se que, em sete deles, estavam presentes indicações de parlamentares com características de agenda holders.

Cabe explicar que, nos casos de apropriação, exigese que o pesquisador realize a análise de cada etapa do processo, de modo a visualizar, em primeiro lugar, qual proposição legislativa resultou da apropriação. Dessa forma, é importante distinguir qual foi o "produto", e qual foi o "objeto" da apropriação, especialmente em que estágio encontrava-se no momento da formalização da proposição pelo Executivo.

\section{IV.1. Casos de apropriação}

No primeiro desses casos, o produto da apropriação foi parte da medida provisória que originou as regras do programa Minha Casa Minha Vida (PMCMV). Essa medida provisória (MP 459/2009) teve o seu capítulo sobre regularização fundiária totalmente baseado em um texto produzido na Câmara dos Deputados, no âmbito do processo em que se discute, há anos, a futura Lei de Responsabilidade Territorial Urbana (LRTU) (PL 3 057/2000 e apensos). O objeto da apropriação foi o substitutivo produzido pelo último relator, o Deputado Renato Amary (PMDB-SP), que estava pronto para a votação em plenário.

Amary era deputado federal de primeiro mandato, mas também era um político experiente, com passagem pela Assembleia Legislativa do estado de São Paulo e dois mandatos como prefeito de Sorocaba, uma das maiores cidades do estado de São Paulo. Além disso, como é empresário do setor imobiliário, era especialista nos assuntos debatidos no âmbito da LRTU.

Esse parlamentar mostrou sua capacidade de articulação política com a aprovação, em 2007, de seu substitutivo pela comissão especial criada na Câmara para tratar da matéria. O processo já havia passado por três relatores sem sucesso. Trata-se de debate que envolve conflitos entre loteadores e incorporadores imobiliários, entidades que integram o movimento da reforma urbana, o Ministério das Cidades, o Ministério do Meio Ambiente e organizações não governamentais ambientalistas, órgãos de defesa do consumidor, registradores imobiliários e outros atores (ARAÚJO, 2008).

Mesmo com a aprovação na comissão especial, Amary não teve força para assegurar a colocação de seu texto em pauta para votação final no plenário da 
Câmara, situação que, provavelmente, decorreu do esfriamento da demanda política pela LRTU após a ocorrência da apropriação e a consequente inclusão das normas sobre regularização fundiária na Lei do PMCMV. Assim, apesar de ter atuado como um agenda holder nos debates sobre a LRTU, Amary não obteve sucesso na fase final do processo na Câmara. Como o parlamentar era, à época, filiado ao PSDB, a condição de oposicionista na coordenação de tema com relevante repercussão social pode ter levado o Executivo a incorporar o assunto na referida medida provisória, auferindo os dividendos eleitorais potencialmente gerados pela autoria das normas nacionais sobre regularização. Em face do gigantesco número de favelas e outras ocupações irregulares nas cidades brasileiras, cabe considerar que a votação final da LRTU, que não ocorreu até hoje, poderia ter contribuído positivamente para a reeleição do parlamentar. $\mathrm{O}$ seu pouco tempo de Câmara é outro aspecto que necessita ser ponderado. Ele pode não ter tido oportunidade de consolidar a rede de relacionamentos necessária para fazer avançar uma matéria complexa como essa (ARAÚJO \& SILVA, 2013).

No segundo caso em que foi identificada a presença de um agenda holder, o produto da apropriação foi a medida provisória que gerou as normas nacionais sobre o acesso a medicamentos a baixo custo (MP 154/2003). O objeto da apropriação foi um projeto de lei de autoria do Deputado Eduardo Jorge (PV-SP), que se propunha a disciplinar as farmácias populares (PL 4 702/1994).

Eduardo Jorge era um parlamentar especializado em saúde e seguridade social, tendo posteriormente estendido sua atuação para a questão ambiental. É um político experiente, que reunia, à época, um mandato como deputado estadual e quatro como deputado federal, então pelo Partido dos Trabalhadores (idem).

$\mathrm{Na}$ documentação relativa a esse processo legislativo, não há indicativos de que Eduardo Jorge tenha sido chamado pelo governo para negociar a apropriação. Considera-se, contudo, que sua condição de agenda holder permitiu que ele auferisse proveitos políticos da lei do Executivo que foi aprovada. A ideia da "farmácia popular" permaneceu ligada a ele. Registre-se que, no decreto que viria a regulamentar a lei, a própria denominação "farmácia popular" foi textualmente aproveitada.

No terceiro caso que apresenta interesse para a análise sobre os agenda holders, o produto da apropriação foi parte do conteúdo da medida provisória que gerou a Lei do Fundo de Manutenção e Desenvolvimento da Educação Básica e de Valorização dos Profissionais de Educação - (Fundeb) (MP 339/ 2006). O objeto da apropriação foi o estabelecimento de regras sobre controle social constantes em substitutivo de autoria da Deputada Fátima Bezerra (PT$\mathrm{RN}$ ), relativo a um projeto de lei que dispunha sobre o assunto (PL 241/1999).

Bezerra é pedagoga, com dois mandatos como deputada estadual e três como deputada federal. Considera-se que essa parlamentar é uma agenda holder especializada em educação e cultura, permanecendo hoje com essa qualificação (idem). No processo de apropriação estudado, evidencia-se a negociação do Executivo com a parlamentar, uma vez que ela foi a relatora da medida provisória da Lei do Fundeb.

No quarto caso, tem-se como produto da apropriação o projeto de lei complementar de autoria do Executivo, apresentado em 2008, que dispunha sobre a cooperação entre os entes federados em termos de política ambiental (PLP 388/2007). O objeto da apropriação foi um projeto exatamente com o mesmo objetivo, o PLP 12/2003, de autoria do Deputado Sarney Filho (PV-MA). A proposta do governo foi apensada ao processo previamente em curso, que gerou a lei complementar três anos depois. Não se pode dizer que o parlamentar obteve proveito político com a apropriação ocorrida. Ele participou diretamente do processo de negociação do diploma legal aprovado, em atuação típica de agenda holder, mas sofreu derrota na votação final em relação a parte do texto. Essa lei complementar tem recebido críticas de algumas entidades ambientalistas.

Sarney Filho tem histórico familiar forte de envolvimento na política, tem oito mandatos consecutivos como deputado federal, com atuação especializada na questão ambiental. Foi Ministro do Meio-Ambiente entre 1999 e 2002 e coordena a Frente Parlamentar Ambientalista (idem).

No quinto caso, o produto da apropriação foi a medida provisória que gerou lei concedendo pensão especial às pessoas atingidas pela hanseníase, submetidas a isolamento e internação compulsórios (MP 373/2007). Trata-se de um caso de cópia literal de uma proposição pelo Executivo. O objeto da apropriação foi projeto de lei de autoria do Senador Tião Viana (PT-AC), o PLS 206/2006. O parlamentar participou do processo de apropriação, tendo assumido a relatoria da referida medida provisória.

Viana tem formação profissional em medicina tropical e foi governador do Acre. No banco de dados do Senado, constam duas centenas de processos por ele relatados, o que indica a consolidação como articulador político, elemento básico da qualificação como agenda holder, independentemente da especialização temática. 
No sexto caso, o produto da apropriação foi o projeto de lei de autoria do Executivo que gerou a Lei da Política Nacional sobre Mudança do Clima (PL 3 535/2008). O objeto de apropriação foram dois projetos de lei, o PL 18/2007 e o PL 261/2007, de autoria respectivamente do Deputado Sarney Filho e do Deputado Antônio Carlos Mendes Thame (PSDBSP).

Assim como Sarney Filho, Thame é um parlamentar especializado em meio ambiente, tendo seis mandatos como deputado federal. Professor universitário na área de agronomia, ele foca com atenção especial as interfaces da questão ambiental com os temas agricultura e energia. Coordena o grupo de trabalho sobre energias renováveis da Frente Parlamentar Ambientalista (idem).

Thame foi relator do projeto de lei que foi produto da apropriação. Note-se que a especialização do parlamentar e o fato de ele ser autor de proposta sobre o assunto contribuíram para que ele assumisse a relatoria de um processo de interesse direto do Executivo, mesmo sendo um deputado da oposição.

Por fim, no sétimo caso, coloca-se como produto da apropriação a medida provisória que alterou a Lei de Licitações, dispondo sobre o limite da área rural que pode ser transferida sem licitação na Amazônia (MP 422/2008). Trata-se de outro caso de cópia literal de uma proposição pelo Executivo. O objeto da apropriação foi projeto de lei de autoria do Deputado Asdrúbal Bentes (PMDB-PA), o PL 2 278/2007.

Bentes é advogado com histórico de atuação em questões fundiárias. Deputado Federal com seis mandatos, um número relevante de relatorias estão registradas em seu nome. No caso em tela, ele atuou como relator do produto da apropriação, o que indica relações diretas de coordenação com o Executivo. Há indicativos de que os benefícios auferidos por ele a partir do processo de apropriação foram significativos. Ele foi escolhido para relatar, posteriormente, uma medida provisória bem mais ampla sobre a regularização das ocupações em terras da União na Amazônia (MP 458/2009).

\section{IV.2. Comentário dos casos}

Os achados da análise dos agenda holders identificados nos processos em que ocorreu apropriação da agenda do Legislativo apontam que "[...] para ser e se estabelecer ao longo do tempo como agenda holder, são relevantes (i) o passado do indivíduo, sua biografia, suas possíveis especializações (que aqui também tratamos como o tema focalizado pelo parlamentar); (ii) a seniority no Congresso; e (iii) sua capacidade de negociação" (ARAÚJO \& SILVA,
2013, p. 306).

Entende-se que, para que sejam auferidos benefícios para a carreira política, a condição de agenda holder exige um esforço inicial do parlamentar no sentido de construção de uma rede de relacionamentos no Congresso Nacional, que pode ser alcançada pela especialização temática e pela habilidade de negociação com seus pares. Dos sete parlamentares citados acima, seis deles, em maior ou menor grau, podem ser considerados como especialistas, com atuação política direcionada a assuntos determinados. Em certos momentos, essa especialização impulsiona até mesmo a diluição da barreira entre partidos da base e da oposição, como no caso de Thame.

Apenas Viana surge como um parlamentar que, mais do que especialização, buscou-se consolidar na função de relator. Contudo, a importância desse perfil para a qualificação como agenda holder não pode ser desconsiderada, em face do reduzido número de casos analisados neste tópico. Além disso, os parlamentares "especialistas" estudados também acumulavam histórico com número relevante de relatorias.

Praticamente todos os agenda holders identificados tinham bastante tempo de Congresso Nacional. Amary é exceção, mas seu pouco tempo no Legislativo federal pode ter sido exatamente um dos fatores que dificultou que ele fosse bem sucedido tendo em vista a votação final da LRTU.

\section{AGENDA HOLDERS E AS COMISSÕES ESPECIAIS DA CÂMARA ${ }^{10}$}

De acordo com o art. 34 do Regimento Interno da Câmara dos Deputados, as comissões especiais são constituídas para dar parecer sobre: (i) proposta de emenda à Constituição; (ii) projeto de código e (iii) proposições que versarem matéria de competência de mais de três comissões que devam pronunciar-se quanto ao mérito, por iniciativa do presidente da Câmara, ou a requerimento de líder ou de presidente de comissão interessada. Nesse último caso, pelo menos metade dos membros titulares da referida comissão deve ser formada por membros titulares das comissões permanentes que deveriam ser chamados a opinar sobre a proposição em causa. Como regra geral, passa a ser atribuição da comissão especial o exame de admissibilidade e do mérito da proposição em tela e das emendas que the forem apresentadas, podendo ainda ter poder conclusivo para alguns casos, se não houver recursos para deliberação pelo plenário.

\footnotetext{
10 Para uma síntese dos casos aqui tratados, recomendamos a leitura da tabela constante no Anexo II.
} 
Há impactos potenciais sobre a alternativa pelas comissões especiais, em substituição às de comissões permanentes. Comandadas apenas por um presidente e um relator, elas constituem um mecanismo de centralização das decisões. É justamente por isso que esse expediente tem sido sistematicamente usado pelo Executivo como forma de garantir rapidez e reduzir as possibilidades de mudança em suas proposições encaminhadas na forma de projetos de lei. O controle dos líderes governistas na indicação dos nomes para a coordenação dessas comissões e no resultado final dos trabalhos, não resta dúvida, é maior do que no trâmite normal nas comissões permanentes. Desse modo, ganha relevo a questão da disciplina partidária e do posicionamento do partido político frente à matéria em análise.

Nos últimos anos, essa ferramenta tem sido usada com bastante frequência, notadamente em temas de impacto na sociedade, tendo levado ao esvaziamento da pauta de determinadas comissões permanentes. Esse uso estratégico das comissões especiais na Câmara, constituídas nos processos que envolvem matéria do mérito de mais de três comissões, ainda não mereceu atenção da Ciência Política. Registre-se que esse instrumento não existe no Senado.

Entende-se que essas comissões especiais são arenas privilegiadas para a análise de agenda holders. Como um relator apenas, que se manifestará tanto sobre o mérito quanto sobre a admissibilidade jurídica e, se for o caso, orçamentária, elas potencializarão a atuação parlamentar no sentido da articulação política, de negociação com os diferentes grupos governamentais e não governamentais envolvidos no debate de cada assunto. Basta observar que a realização de audiências públicas é atividade sistemática nessas comissões ${ }^{11}$. Na análise realizada sobre as 33 comissões especiais constituídas na $53^{\mathrm{a}}$ Legislatura na Câmara dos Deputados, verificou-se que apenas três delas não realizaram audiências públicas.

\footnotetext{
11 É preciso destacar que não resta dúvida acerca da atuação de agenda holders nas comissões permanentes. Ocorre que a centralização provocada pela criação de comissão especial torna mais perceptível o trabalho desses atores. As atividades dos agenda holders nas comissões permanentes devem ser estudadas caso a caso, demandando uma análise dos atores na tramitação de cada matéria, que frequentemente passa por mais de uma comissão e, portanto, pelas mãos de mais de um relator. Isso exige do pesquisador um esforço de investigação mais detalhado ainda para distinguir as ações dos parlamentares e verificar o grau de influência de cada um no processo. A estratégia de estudar casos de apropriação é uma das formas de analisar a atuação dos agenda holders também no âmbito dos processos que tramitam pelas comissões permanentes.
}

Com variações naturais em razão das especificidades do objeto de cada comissão, em geral foram ouvidos nessas reuniões tanto representantes dos diferentes poderes da república, com destaque natural para o Executivo federal, quanto representantes do empresariado, da sociedade civil e da academia ${ }^{12}$.

Mesmo considerando os limites da $53^{\mathrm{a}}$ Legislatura, constam três casos de deputados que trabalharam na relatoria de duas comissões especiais, o que configura forte indício de atuação como agenda holders. Vejamos esses casos.

O Deputado João Maia (PR-RN) é deputado de segundo mandato ${ }^{13}$, mas vem de cargos importantes no Executivo em diferentes níveis de governo. No sistema de controle da Câmara, constam dez projetos de lei ordinária de sua autoria e 59 processos relatados, o que parece indicar uma opção pela atividade de relatoria. O parlamentar foi relator da comissão especial que se debruçou sobre a Lei do Gás (PL 334/2007 e apensos) e da comissão especial que analisou um dos projetos de lei relacionados à exploração do Pré-Sal, a proposta relativa ao exercício das atividades de pesquisa e lavra de petróleo, de gás natural e de outros hidrocarbonetos fluidos pela Petrobrás (PL 5 941/2009). Em ambos os casos, houve seis audiências públicas e formulação de substitutivo às proposições originais pelo relator. Esses processos contribuíram na publicação da Lei 11 909/2009 e da Lei 12 276/2010. Sem prejuízo da necessidade de análise de outros fatores envolvidos, o sucesso na aprovação do texto em lei evidencia o papel de um relator que atua como agenda holder com papel de relevo nas negociações políticas e, também, ameniza o grau de conflito entre os atores envolvidos, também funcionando como policy broker (SABATIER \& JENKINS-SMITH, 1993; 1999) A confirmação efetiva dessa atuação demandaria estudo detalhado dos dois processos legislativos.

Outro caso é do Deputado Carlos Zarattini (PT$\mathrm{SP})$. No seu segundo mandato ${ }^{14}$, com mandato anterior no legislativo estadual, possui registrados como de sua autoria 22 projetos de lei ordinária e 29 processos relatados. O parlamentar foi relator da comissão especial referente à tarifa social de energia elétrica (PL $1921 / 1999$ e apensos) e da comissão especial que tratou da desoneração tributária do transporte (PL 1 927/2003 e apensos). Em ambos os casos, houve sete audiências públicas e formulação de substitutivo às

\footnotetext{
12 Para a lista dos nomes ouvidos nas audiências públicas, cf. Brasil (2013).

13 Legislaturas de 2007-2011 e 2011-2015.

14 Legislaturas de 2007-2011 e 2011-2015.
} 
proposições originais pelo relator. O primeiro processo repercutiu na publicação da Lei 12 212/2010 e o segundo ainda tramita, tendo sido o texto do relator aprovado na comissão especial e remetido diretamente ao Senado. Nos dois processos, manteve-se o poder conclusivo da comissão que o analisou, ou seja, não houve aprovação de recurso para análise pelo plenário, o que indica consenso sobre os textos produzidos.

O Deputado Jorginho Maluly (DEM-SP) surge como relator na comissão especial sobre contratos de seguro privado (PL $3555 / 2004$ e apensos) e da comissão especial da reforma universitária (PL 4 212/ 2004 e apensos). Esse caso é interessante, pois mostra que a repetição de atuações na relatoria, isoladamente, não pode ser adotada como caracterização do agenda holder. Se na comissão da reforma universitária foram ouvidos atores relevantes em seis audiências públicas, bem como produzido parecer pelo parlamentar, que não chegou a ser votado, na comissão sobre contratos de seguro privado foram realizadas três audiências, mas sequer foi apresentado parecer. Registre-se que Maluly não foi reeleito.

$\mathrm{Na}$ lista de comissões especiais da $53^{\mathrm{a}}$ Legislatura, surge o Deputado Henrique Eduardo Alves (PMDB$\mathrm{RN}$ ), que foi relator na comissão especial de uma das propostas legislativas relacionadas ao Pré-Sal (PL 2 502/2007 e apensos). Alves relatou, também, a medida provisória que gerou a Lei do PMCMV, citada nos casos de apropriação por envolver parte do conteúdo da futura LRTU.

Esse parlamentar, certamente um dos mais experientes do Congresso Nacional, com 11 mandatos de deputado federal ${ }^{15}$, tem assumido relatorias de processos com maior relevância nos últimos anos, firmando-se como articulador político independentemente de tema. Note-se que nem todos os líderes partidários buscam relatorias de relevo, o que parece reforçar a qualificação de Alves, pelo menos atualmente, como um agenda holder.

Como mencionado anteriormente, há alguns casos de parlamentares que, no decorrer dos anos, firmam atuação em torno de temáticas específicas, consolidando-se como agenda holders especializados. Os principais atores envolvidos nesses temas de políticas públicas sabem, de antemão, que as negociações sobre as propostas legislativas, como regra, passarão por determinado parlamentar especializado. $\mathrm{Na}$ lista de relatores das comissões

15 Legislaturas de 1971-1975, 1975-1979, 1979-1983, 19831987, 1987-1991, 1991-1995, 1995-1999, 1999-2003, 20032007, 2007-2011 e 2011-2015. especiais da $53^{\text {a }}$ Legislatura, podemos citar a Deputada Rita Camata (PSDB-ES). Especialista nas causas relativas a mulheres, crianças e adolescentes, a parlamentar foi relatora na comissão especial do atendimento socioeducativo (PL 1 627/2007), em processo no qual ficou caracterizada a atuação como agenda holder e que gerou a Lei 12 594/2012. Apesar de não ter sido reeleita para a atual legislatura, Camata vinha de vários mandatos como deputada federal ${ }^{16}$.

Na relatoria da comissão especial do Estatuto da Juventude (PL 4 529/2004 e apensos), tem-se parlamentar que também parece estar seguindo o caminho da especialização, a Deputada Manuela D’Ávila (PCdoB-ES). No referido processo legislativo, parece caracterizada a atuação como agenda holder, com concentração das negociações nos entes governamentais, que estiveram presentes em praticamente todas as oitivas públicas.

Merece ser analisado em particular o polêmico processo da nova lei florestal, também objeto de comissão especial da Câmara na 53 ${ }^{\mathrm{a}}$ Legislatura (PL 1.876/1999 e apensos). Foram realizadas 14 audiências públicas para o debate do projeto, além de um bom número de reuniões públicas nos estados. Não se pode colocar em dúvida que o relator, Deputado Aldo Rebelo (PCdoB-SP) envolveu-se com vigor nas negociações com um conjunto grande de atores governamentais e não governamentais. No entanto, a atuação como agenda holder circunscreveu-se pela evidenciada postura a favor das demandas das entidades representativas dos produtores rurais, o que parece ter contribuído para o acirramento dos conflitos entre os atores partícipes dos debates, não para sua redução. Dessa forma, foi um agenda holder que se distanciou do papel de policy broker.

Avalia-se que, em determinados processos, o forte controle do Executivo não favorece a atuação do relator como agenda holder, mesmo que tenham ocorrido algumas audiências públicas e votação. Esse é o caso das comissões do PL 3 960/2008 (cargos no Bacen e pesca), do PL 5 939/2009 (Pré-Sal/Petrosal) e do Projeto de Lei Complementar (PLP) 001/2007 (limites de despesa com pessoal).

Fator fundamental para a ausência de caracterização do agenda holder, evidentemente, é a não apresentação de parecer pelo relator, em processos nos quais houve tempo hábil para isso ocorrer. Ademais, deve-se atentar para o fato de que nem sempre o relator é o único

16 Legislaturas de 1987-1991, 1991-1995, 1995-1999 e 20072011. Mencione-se que, em 2009, a parlamentar saiu do PMDB após mais de 25 anos de militância no partido. 
agenda holder no processo. Nas comissões especiais analisadas, há casos em que há indicativos de que o presidente do órgão colegiado atuou como articulador das negociações e viabilizou a votação. Para a constatação do que coube exatamente ao relator e ao presidente, todavia, faz-se necessário rastrear detalhadamente cada processo legislativo ${ }^{17}$.

\section{AGENDA HOLDERS E AS MEDIDAS PROVI- SÓRIAS ${ }^{18}$}

Sabe-se que, por diversos motivos, até além dos autorizados legalmente, o governo recorre ao instrumento das medidas provisórias (MPs), que constituem uma maneira imediata para efetivar-se uma inovação jurídica e, ao mesmo tempo, obter uma decisão do Legislativo em um prazo extremamente curto. Nesse quadro, há de se lidar com as consequências imediatas da norma para estabelecer emendas ao texto. Isso impõe um grande custo e um amplo desafio para os parlamentares que estiverem relatando a proposta em cada uma das casas do Congresso Nacional.

Nos processos das MPs, o governo age no sentido de diminuir ao máximo os riscos de alteração indesejada no texto, atuando, assim, de maneira importante na escolha dos relatores. No entanto, como já foi dito, a alteração no texto é bastante comum, o que leva a um questionamento: será que existe um problema de seleção adversa dos relatores ou o processo legislativo é de tal forma controlado pelo Executivo, que todas as alterações são autorizadas? $\mathrm{Na}$ verdade, esses dois aspectos representam extremos de um espectro de possibilidades que acontecem no dia-a-dia das discussões das MPs. E, certamente, entendemos que haverá espaço para encontramos os agenda holders nesse espectro.

Primeiramente, deve-se levar em consideração que a tramitação das MPs envolve processos bastante concentrados (assim como nas comissões especiais abordadas na seção anterior), o que, tendo em vista os

17 Recomendamos a leitura do Anexo II, onde estão sistematizadas todas as informações coletadas acerca das comissões especiais durante a $53^{\mathrm{a}}$ Legislatura.

18 Ver Anexo III. Entre setembro de 2001 e março de 2012, o Congresso Nacional não formalizou, na prática, as comissões mistas previstas na Constituição Federal para análise das MPs. A primeira data refere-se à Emenda Constitucional 32/2001, que mudou o prazo de validade desses atos. A segunda data diz respeito à decisão do Supremo Tribunal Federal (STF) que obrigou o Legislativo a observar a regra das comissões mistas. As análises inclusas nessa seção tomam como material empírico as MPs da $53^{a}$ Legislatura. Assim, consideram as regras de tramitação que valeram até março de 2012. curtíssimos prazos de discussão, impõe uma capacidade de responsabilização extra aos relatores. Isso ocorre tanto pela característica do processo das MPs em si como pelo interesse e pressão do Executivo, em situações que podem direcionar encaminhamentos do tipo "aprovar sem acatar mudanças", "em algumas partes, podem-se abrir negociações" ou até mesmo "preciso de você para articular esses temas polêmicos e conciliar os interesses do Congresso e os nossos". Cada um desses exemplos reflete um tipo de postura e, principalmente, depende do perfil do parlamentar atuando na relatoria, do que se depreende a relevância da seleção desses parlamentares. Serão escolhidos, nessa perspectiva, os bons delegados ou os bons articulares.

Em segundo lugar, quando se observa a atuação dos parlamentares, é fundamental as idiossincrasias da Câmara e do Senado, não apenas pelas diferenças conhecidas sobre perfil, funções, tipo de eleição e regras próprias, entre outros pontos, mas também pelas diferenças nos padrões de condução da tramitação das MPs. Por exemplo, sabe-se que o Senado pode até fazer alterações no texto aprovado pela Câmara, mas está limitado a ver se suas propostas são aceitas ou não pela câmara baixa ${ }^{19}$. No entanto, a questão que mais vem impondo condições mais ou menos adversas ao Senado (e, ao respectivo relator) são os prazos de tramitação distorcidos entre as duas casas do Congresso. Como está estabelecido na Constituição, o Congresso Nacional tem 120 dias de prazo para votar a MP20, prazo esse que não conta durante o recesso parlamentar. Ocorre que a Câmara dos Deputados utiliza muito mais desse tempo para as suas discussões, como até era de se esperar, tendo em vista a quantidade de parlamentares e a complexidade que isso implica. Não obstante, o tempo utilizado pelas casas vem sendo cada vez menos favorável ao Senado, conforme podemos verificar no Gráfico 1 .

Observe-se que os prazos menores estabelecem condicionamentos relevantes aos relatores do Senado, especialmente no ano de 2010 , onde houve um recrudescimento da diferença entre as casas e, naturalmente, uma menor frequência observada nas mudanças realizadas pelos senadores relatores. Isso mostra que, na Câmara, os relatores tinham muito mais

19 Cabe lembrar que todas as proposições apresentadas pelo Poder Executivo passam primeiramente pela Câmara dos Deputados, por previsão da Constituição Federal.

20 Após a Emenda Constitucional 32/2001, a MP vale por sessenta dias, prazo que pode ser prorrogado uma vez por mais sessenta dias. Na prática, essa prorrogação tem sido realizada de forma automática. 
espaço de ação que no Senado, casa na qual tal ação depende não só da capacidade técnica ou de articulação, mas de lidar com tempo hábil para realizar o trabalho.

\section{GRÁFICO 1 - PRAZOS DE TRAMITAÇÃO DAS MPS EM CADA CASA LEGISLATIVA (2007-2010)}

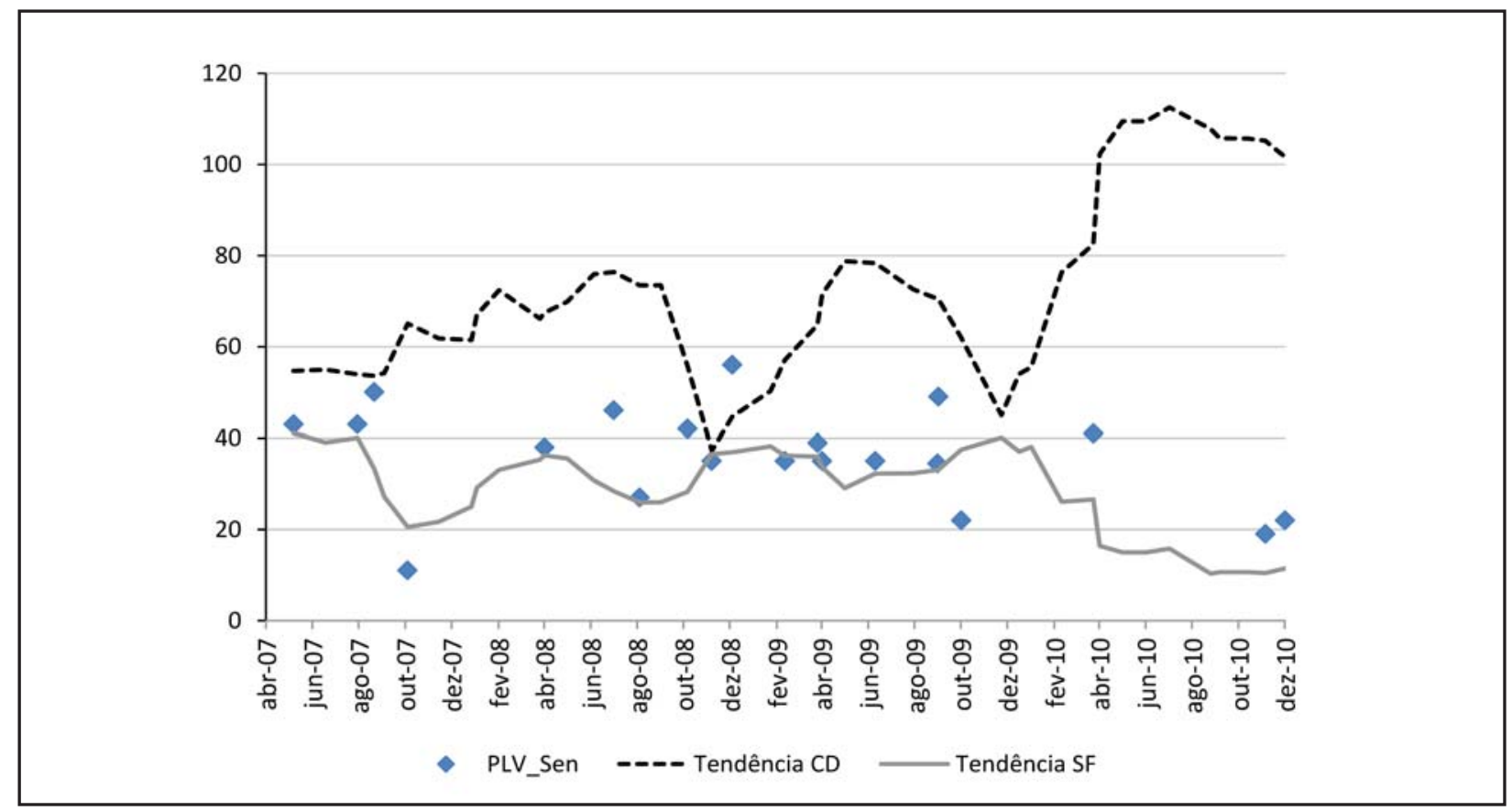

FONTE: Os autores, com base em dados da Câmara dos Deputados e do Senado Federal.

NOTAS:

1. As curvas de tendências foram obtidas por meio de média móvel para os prazos de cada MP coletados em cada casa legislativa.

2. Os pontos de dados significam os prazos de tramitação, ocorridos no Senado, de textos que sofreram alteração e retornaram à Câmara.

Outro aspecto que deve ser levado em conta é que os senadores já têm acesso a todas as informações sobre o processo decisório ocorrido na Câmara e, não raro, também participam indiretamente dele, implicando um conhecimento prévio sobre os detalhes da matéria e incluindo a avaliação relativa à necessidade real de fazerem-se mudanças no texto. Tais considerações fazem-nos crer que, a princípio, poderia haver maior ocorrência de atuação de parlamentares com perfil de agenda holders na Câmara que no Senado. Por fim, é importante ressaltar que, por serem MPs, haverá claramente uma predominância de relatores dos partidos que constituem a base do governo.

Espera-se que o relator seja um agenda holder quando forem observados elementos de que ele exerceu capacidade de articular as demandas dos parlamentares (e, indiretamente, nos setores interessados) e os interesses do governo.

Dado esse panorama, apresentaremos algumas maneiras de estudar a atuação dos agenda holders nas
MPs. Para esse exercício, adotaremos o corte da $53^{\mathrm{a}}$ Legislatura (2007-2010), como foi feito em relação às comissões especiais. Além disso, realizamos uma seleção na base de dados, eliminando situações onde não faria muito sentido buscar atuação de agenda holders, tais como (i) MPs rejeitadas, revogadas ou que foram consideradas sem eficácia e (ii) proposições de créditos extraordinários (em relação às quais o Congresso nunca realizou nenhuma mudança). Retirados esses processos, para o período proposto, foram analisadas 115 medidas provisórias ${ }^{21}$.

Na Câmara, os relatores são escolhidos após a apresentação das emendas à MP, apresentadas tanto

\footnotetext{
21 É importante destacar que as análises levaram em consideração a ordem e as circunstâncias impostas pelo processo legislativo das MPs, o que incorpora abordagens específicas para cada uma das casas legislativas. Para obter o levantamento completo das medidas provisórias e os agenda holders durante o período de 2007-2010, cf. Silva e Araújo (2013).
} 
por deputados quanto por senadores. Entendemos que, para verificar a situação de agenda holder, é preciso conjugar a complexidade do trabalho e o nível de sensibilidade política perante as demandas demonstradas pelo Congresso. Dessa forma, dois fatores serão importantes para determinar o curso da ação do relator: (i) a quantidade de dispositivos do texto, que indica a complexidade da matéria e (ii) o número de emendas apresentadas, que representa o interesse do Congresso. Com esses dados, criaremos dois parâmetros de avaliação: a atratividade e a aceitação.
A atratividade corresponde à simples razão entre a quantidade de emendas apresentadas e a quantidade de artigos do texto da $\mathrm{MP}^{22}$. Seu resultado retorna um nível aproximado do interesse despertado pela MP e também mostra o grau de desafio do relator para lidar com as demandas existentes. A aceitação é o resultado do trabalho do relator, pois é a razão entre a quantidade de emendas aceitas e o total de emendas. Ela representa o grau de atendimento das demandas dos parlamentares. Assim, estabelecemos critérios para verificar se o relator pode ter exercido ou não o papel de agenda holder, expostos no Quadro 1.

QUADRO 1 - MPS E AGENDA HOLDERS: CRITÉRIOS DE ANÁLISE NA CÂMARA

\begin{tabular}{|lcccc|}
\hline Atratividade (At) & Aceitação (Ac) & Papel do relator & Descrição \\
\hline$\uparrow$ (grande) & $\uparrow$ (grande) & Agenda holder & $\begin{array}{c}\text { Demonstrou capacidade de } \\
\text { articular as demandas em questões. }\end{array}$ \\
\hline$\uparrow$ (grande) & $\downarrow$ (pequena) & Anti-agenda holder & Não foi sensível às demandas. \\
\hline $\begin{array}{l}\text { (pequena) } \\
\downarrow \text { (pequena) }\end{array}$ & $\uparrow$ (grande) & $\begin{array}{c}\text { Neutro, de acordo com } \\
\text { o esperado pelo governo }\end{array}$ & $\begin{array}{c}\text { A característica do processo não } \\
\text { revelou nenhuma necessidade } \\
\text { de articulação demandas } \\
\text { vis-à-vis complexidade do tema. }\end{array}$ \\
\hline
\end{tabular}

FONTE: Os autores.

A distinção dos critérios entre "grande" ou "pequena" dependerá da amostra analisada. No nosso caso, para diferenciar a atratividade, levamos em consideração o resultado que representou o primeiro quartil de nossa amostra, que foi a razão de atratividade de $1,4($ At $=1,4)$. Essa escolha justifica-se pelo fato de que poderíamos ter excluídas MPs de grande complexidade e que tiveram demanda em proporção semelhante ao número de artigos. Relativamente à aceitação, levamos em consideração que deveríamos escolher um parâmetro que refletisse minimamente a atuação ativa de um parlamentar em aceitar alterações no texto baseadas nas emendas. De acordo com as características de nossa amostra, julgamos que a adoção da mediana seria interessante, apresentando uma razão de aceitação de 0,08 ou $8 \%(\mathrm{Ac}=8 \%)$.

De acordo com essas informações, tivemos a presença de aproximadamente $43 \%$ de agenda holders, $33 \%$ de anti-agenda holders e de $24 \%$ de parlamentares com perfil neutro. O que chamou a atenção foi a presença de anti-agenda holders de partidos da oposição, o que reflete, nesses casos, uma aproximação de preferências entre governo e esses parlamentares. Observamos uma grande correlação entre as matérias e os interesses dos parlamentares (pelo tema em si, por ligações regionais etc.) e também verificamos repetições de alguns parlamentares nas relatorias. Tal aspecto, no entanto, não implicou repetição dos mesmos papéis.

A título de exemplificação, notamos dois parlamentares da Câmara bastante presentes nas relatorias, os deputados André Vargas (PT-PR) e Rose de Freitas (PMDB-ES). Segundo nossos parâmetros, nos três casos em que atuou como relator de MP na $53^{\text {a }}$ Legislatura, o Deputado André Vargas foi, em todos, um agenda holder, enquanto a Deputada Rose de Freitas apresentou variação nas três oportunidades, servindo de agenda holder, anti-agenda holder e neutra. Essa questão é interessante, na medida em que o parlamentar pode assumir missões diferentes, obedecendo ou não a um padrão de comportamento. Implica dizer, conforme defendemos desde o começo, que é relevante a complementaridade dos métodos para julgar se tal ou qual parlamentar é um "legítimo" agenda holder. Por enquanto, baseamo-nos nos processos legislativos.

Outro destaque nos relatores mais frequentes é o do Deputado Henrique Eduardo Alves (PMDB-RN),

\footnotetext{
22 Neste trabalho, não foi possível realizar o cálculo por meio do número de dispositivos (artigos, incisos, alíneas e parágrafos). Entendemos que avanços nessa linha refletirão melhor a complexidade do texto das MPs.
} 
pois além de ter sido agenda holder em duas MPs, ele também apresentou esse perfil no que tange aos exemplos estudados na seção sobre as comissões especiais. Nesse caso, confirmou-se, mediante mais de uma metodologia, o perfil de agenda holder, pelo menos nos anos mais recentes da carreira desse parlamentar.

Para os senadores a situação altera-se um pouco. Quando se trata de MPs, qualquer alteração do Senado implica o retorno do texto para a avaliação da Câmara, especificamente naquilo que foi alterado na câmara alta. Isso impõe um custo de transação mais alto ao governo, o que implica uma pressão maior sobre o senador relator. Outro aspecto interessante, decorrente desse primeiro, é que o relator tem de conciliar interesses da Câmara, do próprio Senado e do governo. Dessa forma, embora tenda a ter uma "carga informacional" maior que o relator da Câmara, a conciliação de interesses torna-se mais complexa. A isso se adiciona o fator tempo, que acaba também condicionando a ação do relator senador.

Nessa perspectiva, continuaremos a adotar a razão de atratividade (Ac) como parâmetro de determinação do nível de interesse do Congresso, conciliado com a complexidade do tema, para observar a atuação do relator senador. Ao outro parâmetro chamaremos receptividade $(\mathrm{Rc})$, que representa o número de emendas aprovadas pelo Senado que foram acatadas ao retornar à Câmara dos Deputados. A receptividade mostra a capacidade do senador relator em ter articulado mudanças que representassem a vontade da sua casa de origem e que não ferissem os interesses da Câmara. Daí pode-se também inferir que houve uma articulação bem sucedida com as partes interessadas externas ao Congresso ao longo da etapa final de discussão do texto.

Estabelecemos critérios para verificar se o senador relator pode ter exercido ou não o papel de agenda holder, expostos no Quadro 2.

QUADRO 2 - MPS E AGENDA HOLDERS: CRITÉRIOS DE ANÁLISE NO SENADO

\begin{tabular}{|c|c|c|c|}
\hline Atratividade (At) & Receptividade (Rc) & Papel do relator & Descrição \\
\hline$\uparrow$ (grande) & $\uparrow$ (grande) & Agenda holder & $\begin{array}{l}\text { Demonstrou capacidade de articular } \\
\text { as demandas das duas casas } \\
\text { legislativas, do possível público } \\
\text { externo e do governo. }\end{array}$ \\
\hline$\uparrow$ (grande) & $\downarrow$ (pequena) & Anti-agenda holder & $\begin{array}{c}\text { Não foi bem sucedido na } \\
\text { avaliação das demandas, pois } \\
\text { não conseguiu conciliar diferentes } \\
\text { interesses entre as casas } \\
\text { legislativas ou foi totalmente } \\
\text { insensível às novas demandas. }\end{array}$ \\
\hline$\downarrow$ (pequena) & $\uparrow$ (grande) & Agenda holder & $\begin{array}{l}\text { Levando-se em conta que qualquer } \\
\text { mudança do Senado não pode ser } \\
\text { desprezada, pois provoca o retorno } \\
\text { à Câmara, a elevada receptividade } \\
\text { demonstra um trabalho de articulação } \\
\text { que também não pode ser desprezado. }\end{array}$ \\
\hline$\downarrow$ (pequena) & $\downarrow$ (pequena) & $\begin{array}{l}\text { Neutro, de acordo com } \\
\text { o esperado pelo governo }\end{array}$ & $\begin{array}{l}\text { A característica do processo não } \\
\text { revelou nenhuma necessidade de } \\
\text { aptidão em articular demandas } \\
\text { via-à-vis complexidade do tema }\end{array}$ \\
\hline
\end{tabular}

FONTE: Os autores.

Manteremos a mesma razão de atratividade (At = 1,4). Com relação à receptividade, levamos em consideração que deveríamos escolher um parâmetro que refletisse minimamente o esforço de articulação do senador relator em vista da dificuldade de exercer o papel de agenda holder na câmara alta. Dessa forma, optamos por adotar o primeiro quartil da amostra, apresentando uma razão de receptividade de 0,46 ou
$46 \%(\mathrm{Rc}=46 \%)$.

Os dados do Senado revelam a presença de $20 \%$ de agenda holders, $58 \%$ de anti-agenda holders e de aproximadamente $22 \%$ de parlamentares com perfil neutro, o que correspondeu às nossas expectativas tendo em vista o contexto da relação entre as duas casas legislativas na tramitação das MPs. 
Muito mais do que na Câmara, a repetição de relatores é comum no Senado, embora a variação de posição do relator tenha sido igualmente encontrada. Deve-se destacar o papel da liderança do governo no Senado na ocupação dessas relatorias. O então líder, o Senador Romero Jucá (PMDB-RR), esteve como relator em 18 oportunidades, das quais sete como agenda holder e sete como anti-agenda holder. Podese inferir que o líder que faz papel de agenda holder também atua fortemente em função das necessidades do governo, uma vez que sempre é possível haver ajustes (que igualmente podem ser demandas externas) não devidamente atendidos durante a tramitação da Câmara.

Outro caso interessante chama a atenção para a necessidade de verificarmos mais de um método para constatarmos categoricamente a condição de agenda holder. O Senador Tião Viana (PT-AC) foi um importante agenda holder na formulação da Lei 11 520/ 2007, que dispõe sobre a concessão de pensão especial às pessoas atingidas pela hanseníase que foram submetidas a isolamento e internação compulsórios. Esse senador não foi apenas o autor da proposta praticamente copiada pelo Executivo, como também foi o relator, no Senado, da MP 373/2007 que resultou na lei. Na oportunidade da tramitação, houve uma pequena alteração na Câmara, provocando a formulação de um projeto de lei de conversão (PLV). Quando chegou à câmara alta, o Senador Tião Viana usou de um recurso estratégico, preferindo que a votação da MP precedesse à do PLV. Assim, de acordo com os critérios para as MPs, o Senador foi um antiagenda holder, pois a questão suscitou procura do Parlamento, mas ele, conciliando seus interesses com os do governo, usou da estratégia da não aprovação de qualquer alteração. Em nossa opinião, esse resultado não invalida nossos parâmetros, mas, novamente, desperta atenção para a necessidade de conciliação entre as diferentes metodologias de apuração da função de agenda holder.

\section{CONCLUSÕES}

No campo dos estudos legislativos, muitas vezes as variáveis utilizadas para descrever as atividades do Parlamento não conseguem alcançar toda a complexidade do jogo político e da arena de produção de leis. Os atores mais importantes de cada processo, as proposições de autoria dos próprios parlamentares, as emendas apresentadas aos textos em trâmite e os relatórios, entre outros aspectos que descrevem e explicam o processo legislativo, são raramente analisados. Entendemos que esse quadro colabora de forma relevante para que se alcance uma compreensão apenas parcial da atividade legislativa e de seus produtos, da relação entre os poderes e das carreiras políticas. Dessa forma, a dinâmica do exercício prático da representação política permanece com muitos pontos ainda a serem desvendados.

Assumimos aqui o desafio de trabalhar um tema pouco explorado, qual seja, estudar os parlamentares que assumem destaque na articulação política na arena da produção de leis, os quais tem sido denominamos agenda holders. Os casos estudados neste trabalho evidenciam o papel-chave desses atores políticos em várias propostas, viabilizando-as a se tornarem leis, e como sua atuação fortaleceu suas carreiras políticas, seja para alçar patamares superiores nas hierarquias do poder, seja para manter-se nessa esfera.

Foi possível perceber que o trabalho de mérito sobre mudanças de legislação realizado pelos agenda holders apresenta diferentes características, de acordo com a posição institucional que ocupa (agenda setting) e da disposição para ouvir e conciliar as partes interessadas em cada matéria (policy brokering). Ademais, segundo uma lógica de "agente/principal", podemos verificar que os agenda holders podem ser agentes de atores específicos, tais como grupos de interesse e até o próprio governo. Isso também levanta a questão de que a neutralidade não deve ser vista como condição para ser um agenda holder, ainda que seja algo desejável quando observada a ótica da representação e da democracia.

Ninguém "nasce" dentro do parlamento agenda holder. Para tanto, exige-se um esforço na arena legislativa que vai desde a atuação especializada, a seniority no Congresso e um bom trânsito intra e interpartidos políticos. Os dados e as observações coletadas levam-nos a inferir que há uma relação de retroalimentação entre o status de agenda holder e as carreiras políticas. Por um lado, ser agenda holder é um fator que agrega capital político e fortalece carreiras. Por outro, quanto mais consolidada é a carreira política, maiores possibilidades tem o ator de assumir a condição de agenda holder. Nesse sentido, ser agenda holder pode ser visto como uma identidade política, um reconhecimento por parte de outros atores políticos.

Na pesquisa, foi relevante destacar algumas ponderações vinculadas à figura das lideranças e das relatorias. Mesmo um parlamentar que exerça função formal de liderança partidária não necessariamente tem atuação ativa nas negociações internas ao Congresso Nacional e com o Executivo. Nem todos os líderes são negociadores de destaque nas matérias. O mesmo raciocínio aplica-se aos relatores. Há um número extenso de parlamentares que atuam nos milhares de processos legislativos em curso no Congresso Nacional. Apenas uma parte deles efetivamente realiza trabalho de articulação 
política com os demais parlamentares, o governo e a sociedade em escala que implique contribuições efetivas para a produção legislativa.

A atividade legislativa representa um jogo de múltiplas etapas, idiossincrasias, atores diferenciados e preferências heterogêneas, que demandam a associação de diferentes metodologias para poderem ser compreendidas. Por isso houve a preocupação de levantarmos algumas alternativas objetivas para se estudarem os agenda holders ou, no mínimo, criar condições de seleção de casos para aprofundamento subsequente.

Empregamos, neste trabalho, três abordagens diferenciadas, que incluem estudos de caso e também esforços de cunho quantitativo. Foram abordados os exemplos que envolveram apropriação da agenda do Legislativo, o processo legislativo realizado por meio das comissões especiais na Câmara dos Deputados e a participação dos relatores na tramitação das medidas provisórias.

$\mathrm{Na}$ análise dos exemplos de apropriação, a investigação envolveu detalhamento de casos específicos. Mesmo assim, puderam ser identificados alguns padrões sobre a atuação dos agenda holders e as implicações em termos de carreira. Verifica-se que, para o estabelecimento ao longo do tempo como agenda holder, são importantes o passado do indivíduo e suas possíveis especializações, a seniority no Congresso e sua capacidade de negociação. Esses achados necessitam agora ser testados por outros pesquisadores em outros casos. Considera-se que os processos legislativos em que ficou caracterizada a apropriação são especialmente promissores para a análise da existência e atuação de agenda holders. As situações de apropriação referem-se a proposições legislativas cuja relevância pode ser depreendida do próprio fato de terem atraído o interesse governamental. Elas tenderão, também, a estar associadas a quadros de relação entre os poderes Executivo e Legislativo, e de negociação política, que merecem ser descritos e compreendidos.

Nas comissões especiais da Câmara, ficou evidente que a negociação política não se limita ao Legislativo e ao Executivo. Ela envolve os diferentes representantes da sociedade, que participam formalmente do processo nas audiências públicas e informalmente nos esforços de convencimento dos tomadores de decisão. O grande número de audiências públicas que ocorrem nessas comissões especiais, incluindo um conjunto bastante complexo de atores, aponta para a necessidade de estudos específicos tanto sobre as comissões especiais, quanto para as audiências públicas que acontecem nas comissões permanentes. Em nosso estudo, essas reuniões evidenciaram o trabalho concreto de agenda holders e, também, de atores que fazem o papel inverso, os anti-agenda holders.

Nos processos das medidas provisórias, optou-se por um recorte mais geral, com a proposta de adotar opções metodológicas para a seleção de parlamentares agenda holders. Avalia-se que os critérios de análise desenhados para a Câmara dos Deputados e o Senado Federal geraram achados próximos à realidade. A questão que se coloca é que esses critérios não devem ser aplicados isoladamente de esforços complementares em perspectiva mais qualitativa. Eles funcionam como uma primeira etapa na identificação dos agenda holders e de seu papel. Se e como podem ser aplicados em fóruns diferentes dos processos atinentes às medidas provisórias, são perguntas em aberto. Note-se, nesse ponto, que a recente determinação do Supremo Tribunal Federal para o funcionamento da comissão mista para a apreciação das medidas provisórias pode estabelecer um novo equilíbrio entre deputados e senadores no que tange à possibilidade de atuação como agenda holder. Há fortes possibilidades de que tal comissão retire do relator da Câmara e do plenário daquela Casa as vantagens gozadas até então. Trata-se de uma boa agenda para a continuidade desta pesquisa.

A conjugação de ferramentas metodológicas é um esforço necessário para garantir a robustez dos achados de pesquisa. Apresentamos algumas propostas que dialogam entre si, mas não esgotam os esforços para o estudo dos agenda holders, atores políticos para os quais julgamos que a Ciência Política brasileira poderia dar mais atenção dada sua importância para o desenrolar de matérias relevantes dentro do Congresso Nacional e para uma compreensão mais precisa do nosso sistema político.

Relativamente aos estudos comparados, verificase que há uma promissora agenda de estudo sobre o comportamento dos parlamentares no campo legislativo ${ }^{23}$, pesquisas as quais compartilham do mesmo objetivo deste trabalho, qual seja, o de descobrir como, quando e o quanto atua um congressista na legislação de seu país, e que tipo de parlamentar assume posição de relevo nesse sentido. Deve-se observar que as características da relação entre os poderes, bem como a estrutura e funcionamento das instituições legislativas será determinante no desenvolvimento de metodologias adequadas na detecção de prováveis agenda holders argentinos, chilenos, mexicanos e outros. Este trabalho buscou dar um passo nessa direção.

23 Recentes trabalhos da professora Algazi (2012) e dos professores Ana Maria Mustapic, Alejandro Bonvecchi e Javier Zelasnik (2012) apontam essa tendência. 
Rafael Silveira e Silva (rsilveirasilva@gmail.com) é Doutor em Ciência Política pela Universidade de Brasília (UNB).

Suely Mara Vaz Guimarães de Araújo (suely.araujo@camara.leg.br) é Doutora em Ciência Política pela Universidade de Brasília (UnB).

\section{REFERÊNCIAS BIBLIOGRÁFICAS}

AMES, B. 2003. Os entraves da democracia no Brasil. Rio de Janeiro: FGV.

AMORIM NETO, O. 2006. Presidencialismo e governabilidade nas Américas. Rio de Janeiro: FGV.

AMORIM NETO, O. \& SANTOS, F. 2003. O segredo ineficiente revisto: o que propõem e o que aprovam os deputados brasileiros. Dados, Rio de Janeiro, v. 46, n. 4, p. 661-698. Disponível em: http:/ /www.scielo.br/pdf/dados/v46n4/a02v46n4.pdf. Acesso em: 23.set.2013.

ALGAZI, L. B. 2012. ¿Quién legisla en México? Descentralización y proceso legislativo. Revista Mexicana de Sociologia, Ciudad del Mexico, v. 74, n. 4, p. 619-647, oct.-dic. Disponível em: http:// www.scielo.org.mx/pdf/rms/v74n4/v74n4a4.pdf. Acesso em: 23.set.2013.

ARAÚJO, S. M. V. G. 2008. Lei de Responsabilidade Territorial Urbana: situação atual do debate. Revista de Direito Ambiental, São Paulo, v. 51, p. 232248. Disponível em: http://www.mp.go.gov.br/ portalweb/hp/9/docs/doutrina_urbanismo1.pdf. Acesso em: 23.set.2013.

ARAÚJO, S. M. V. G. \& SILVA, R. S. 2012. Reflexões e novas agendas de pesquisa para os estudos legislativos no Brasil. Revista Ibero-Americana de Estudos Legislativos, Rio de Janeiro, n. 2, p. 5874, out. Disponível em: http://bibliotecadigital.fgv.br/ ojs/index.php/riel/article/viewFile/5847/4546/Acesso em: 23.set.2013.

2013. Agenda holders e carreiras políticas. Revista Brasileira de Ciência Política, Brasília, n. 10, p. 285-311, jan.-abr. Disponível em: http:// www.scielo.br/pdf/rbcpol/n10/09.pdf. Acesso em: 23.set.2013.

FIGUEIREDO, A. \& LIMONGI, F. 2001. Executivo e Legislativo na Nova Ordem Constitucional. $2^{\text {a }}$ ed. Rio de Janeiro: FGV.

2002. Incentivos eleitorais, partidos e política orçamentária. Dados, Rio de Janeiro, v. 45, n. 2, p. 303-343. Disponível em: http:/www.scielo.br/pdf/ dados/v45n2/10790.pdf. Acesso em: 23.set.2013.

GARCÍA MONTERO, M. 2009. Presidentes y Parla- mentos. ¿Quién controla la actividad legislativa en América Latina? Madrid: Centro de Investigaciones Sociológicas.

LEONI, E.; PEREIRA, C. \& RENNÓ, L. 2003. Estratégias para sobreviver politicamente: escolhas de carreiras na Câmara de Deputados do Brasil. Opinião Pública, Campinas, v. 9, n. 1, p. 44-67. Disponível em: http://www.scielo.br/pdf/op/v9n1/ 16151.pdf. Acesso em: 23.set.2013.

LIMONGI, F. \& FIGUEIREDO, A. 2009. Poder de agenda e políticas substantivas. In: INÁCIO, M. \& RENNÓ, L. (orgs.). Legislativo brasileiro em perspectiva comparada. Belo Horizonte: UFMG.

MIGUEL, L. F. 2003. Capital político e carreira eleitoral: algumas variáveis na eleição para o Congresso brasileiro. Revista de Sociologia e Politica, Curitiba, n. 20, p. 115-133, jun. Dispoinível em: http://www.scielo.br/pdf/rsocp/n20/n20a10.pdf. Acesso em: 23.set.2013.

MUSTAPIC,A. M.; BONVECCHI, A. \& ZALEZNIK. J. (comps.). 2012. Los legisladores em el Congreso argentino. Buenos Aires: Institituo Torcuato Di Tella.

PEREIRA, C. \& MUELLER, B. 2000. Uma teoria da preponderância do Poder Executivo: o sistema de comissões no Legislativo brasileiro. Revista Brasileira de Ciências Sociais, São Paulo, v. 15, n. 43, p. 45-67, jun. Disponível em: http://www.scielo.br/ pdf/rbcsoc/v15n43/004.pdf. Acesso em: 29.set.2013.

PEREIRA, C.; POWER, T. \& RENNÓ, L. 2005. Under What Conditions Do Presidents Resort to Decree Power? Theory and Evidence from the Brazilian Case. The Journal of Politics, Statesboro, v. 67, n. 1, p. 178-200, Feb. Disponível em: http:/ / poli s c i.m s u.e du/down loa d s / JOP\%20Pereira\%20Power\%20Renno.pdf. Acesso em: 23.set.2013.

PEREIRA, C. \& RENNÓ, L. 2007. O que é que o reeleito tem? O retorno: o esboço de uma teoria da reeleição no Brasil. Revista de Economia Política, São Paulo, v. 27, n. 4, p. 664-682. Disponível em: http://www.scielo.br/pdf/rep/v27n4/a10v27n4.pdf. Acesso em: 24.set.2013. 
SABATIER, P. A. \& JENKINS-SMITH, H. C. (eds.). 1993. Policy Change and Learning: An Advocacy Coalition Approach. Boulder: Westview.

1999. The Advocacy Coalition Framework: An assessment. In: SABATIER, P. A. (ed.). Theories of the Policy Process. Boulder: Westview.

SANTOS, F. 1997. Patronagem e poder de agenda na política brasileira. Dados, Rio de Janeiro, v. 40, n. 3, p. 465-491. Disponível em: http:/www.scielo.br/ scielo.php?pid=S0011-52581997000300007\& script=sci_arttext. Acesso em: 23.set.2013.

SANTOS, F. \& ALMEIDA, A. 2005. Teoria informacional e a seleção de relatores na Câmara dos Deputados. Dados, Rio de Janeiro, v. 48, n. 4, p. 693-735, out.-dez. Disponível em: http:// www.scielo.br/pdf/dados/v48n4/28477.pdf. Acesso em: 23.set.2013.

SILVA, R. S. \& ARAÚJO, S. M. V. G. 2010. Apropiación de la agenda legislativa: usurpación o cooperación entre los poderes? Trabalho apresentado no V Congreso Latinoamericano de Ciencia Política, realizado em Toronto, Canadá, de 6 a 9 de outubro. Digit. Disponível em: http://www2. congreso.gob.pe/sicr/cendocbib/con3_uibd.nsf/ E7A9F672FA52D1160525789B0058F282/\$FILE/ 3_3575.pdf. Acesso em: 23.set.2013.

2013. Agenda Holder e MPs - para divulgação. Disponível em: https://docs.google.com/file/ d/0B6RNvZn_uRWJNGZaX2ZBMHNLcEE/ edit?pli=1. Acesso em: 23.set.2013.

\section{OUTRAS FONTES}

BRASIL. CÂMARA DOS DEPUTADOS. 2013. Comissões Especiais para dar parecer sobre PEC (encerradas). Disponível em: http://www2.camara. gov.br/atividade-legislativa/comissoes/comissoestemporarias/especiais/53a-legislatura-encerradas. Acesso em: 23.set.2013. 
ANEXO I

AMOSTRA DE PROCESSOS DE APROPRIAÇÃO E COLOCAÇÃO DOS AGENDA HOLDERS

\begin{tabular}{|c|c|c|c|c|c|c|}
\hline & $\begin{array}{l}\text { Proposição } \\
\text { submetida à } \\
\text { apropriação } \\
\text { ("Objeto") }\end{array}$ & $\begin{array}{l}\text { Proposição } \\
\text { do governo } \\
\text { ("Produto") }\end{array}$ & Resultado & $\begin{array}{l}\text { Agenda } \\
\text { holder }\end{array}$ & $\begin{array}{l}\text { Função no } \\
\text { processo }\end{array}$ & $\begin{array}{l}\text { Dados biográficos do } \\
\text { agenda holder }\end{array}$ \\
\hline 1 & $\begin{array}{l}\text { Projeto de Lei } \\
\text { (PL) } 4.702 / \\
1994 \text { na } \\
\text { Câmara dos } \\
\text { Deputados }\end{array}$ & MP 154/2003 & $\begin{array}{l}\text { Lei } 10.858 / \\
2004\end{array}$ & $\begin{array}{c}\text { Eduardo Jorge } \\
\text { (atual PV-SP) }\end{array}$ & $\begin{array}{l}\text { - Autor do } \\
\text { Objeto }\end{array}$ & $\begin{array}{l}\text { Médico sanitarista, } \\
\text { organizador dos } \\
\text { primeiros conselhos } \\
\text { populares de saúde, } \\
\text { esse político foi } \\
\text { secretário de saúde do } \\
\text { município de São Paulo } \\
\text { nos governos de Luiza } \\
\text { Erundina e Marta } \\
\text { Suplicy, deputado } \\
\text { estadual e deputado } \\
\text { federal, à época pelo } \\
\text { Partido dos } \\
\text { Trabalhadores. } \\
\text { Desenvolveu trabalho } \\
\text { de destaque nos } \\
\text { debates da Assembleia } \\
\text { Nacional Constituinte } \\
\text { sobre saúde e } \\
\text { seguridade social. } \\
\text { Secretário do Verde e } \\
\text { Meio Ambiente do } \\
\text { município de São Paulo } \\
\text { entre } 2005 \text { e } 2012 .\end{array}$ \\
\hline 2 & PL 2.491/1999 & MP 339/2006 & $\begin{array}{c}\text { Lei } 11.494 / \\
2007\end{array}$ & $\begin{array}{c}\text { Deputada } \\
\text { Fátima Bezerra } \\
\text { (PT/RN) }\end{array}$ & $\begin{array}{l}\text { - Relatora do } \\
\text { Objeto } \\
\text { - Relatora do } \\
\text { Produto }\end{array}$ & $\begin{array}{l}\text { Pedagoga, com dois } \\
\text { mandatos como } \\
\text { deputada estadual e } \\
\text { três como deputada } \\
\text { federal, a Deputada } \\
\text { Fátima Bezerra tem-se } \\
\text { mantido como titular da } \\
\text { comissão de educação } \\
\text { e cultura da Câmara e } \\
\text { atuado, } \\
\text { essencialmente, em } \\
\text { processos relacionados } \\
\text { a esses temas. No } \\
\text { banco de dados da } \\
\text { Câmara, constam } 28 \\
\text { projetos de lei ordinária } \\
\text { apresentados por ela, e } \\
126 \text { processos } \\
\text { relatados. }\end{array}$ \\
\hline 3 & $\begin{array}{l}\text { Projeto de Lei } \\
\text { Complementar } \\
\text { (PLP) 12/2003 } \\
\text { na Câmara dos } \\
\text { Deputados }\end{array}$ & $\begin{array}{l}\text { PLP 388/ } \\
2007 \text { na } \\
\text { Câmara dos } \\
\text { Deputados }\end{array}$ & $\begin{array}{c}\text { Lei } \\
\text { Complementar } \\
\text { 140/2011 }\end{array}$ & $\begin{array}{l}\text { Deputado } \\
\text { Sarney Filho } \\
\text { (PV/MA) }\end{array}$ & $\begin{array}{l}\text { - Autor do } \\
\text { Objeto }\end{array}$ & $\begin{array}{l}\text { Não obstante o histórico } \\
\text { familiar ser fator a ser } \\
\text { necessariamente } \\
\text { ponderado na análise } \\
\text { da carreira política do } \\
\text { Deputado Sarney Filho, } \\
\text { em oito mandatos } \\
\text { consecutivos como } \\
\text { deputado federal, ele } \\
\text { consolidou uma }\end{array}$ \\
\hline
\end{tabular}




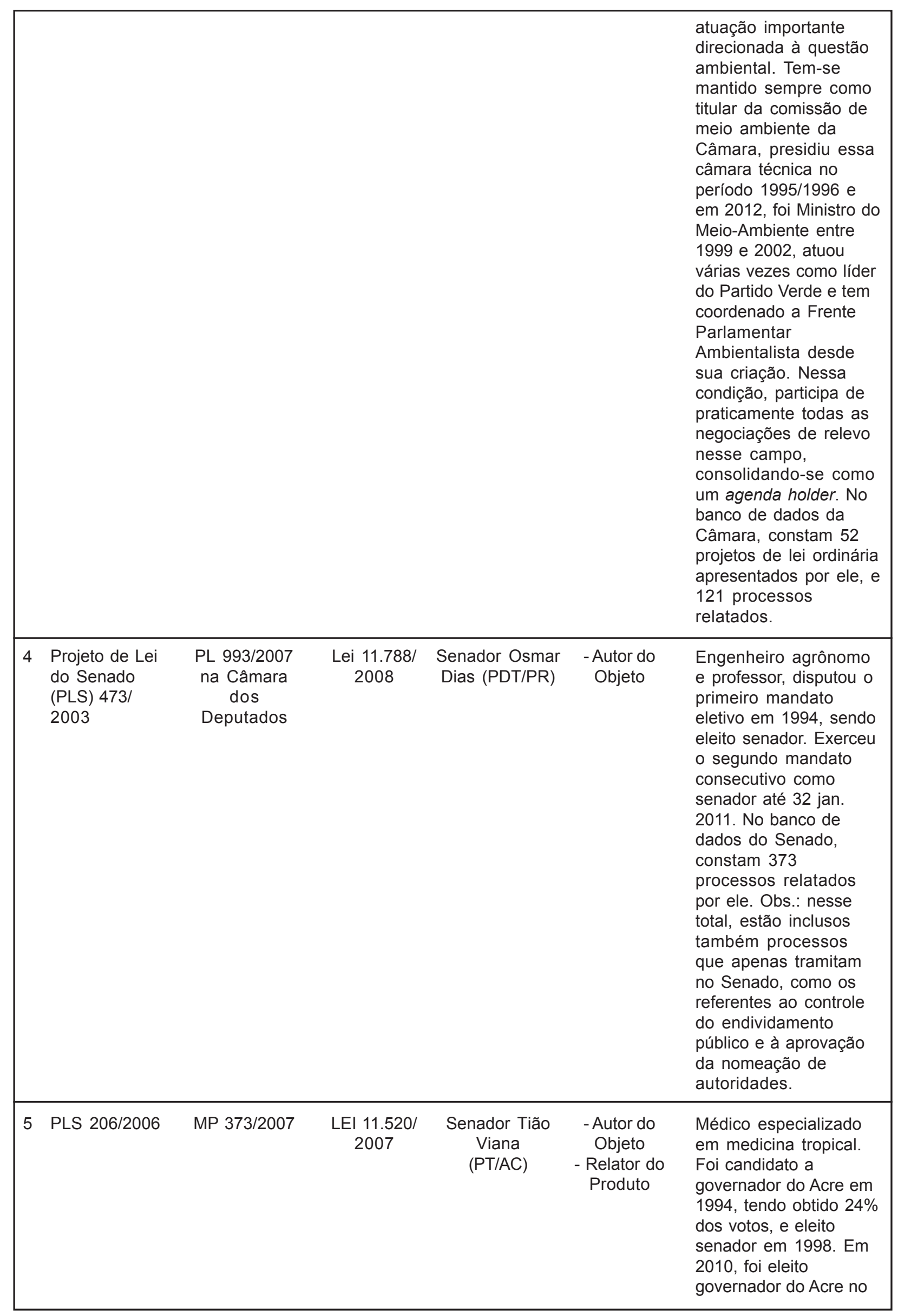




\begin{tabular}{|c|c|c|c|c|c|}
\hline & & & & & $\begin{array}{l}\text { primeiro turno com } 50 \% \\
\text { dos votos válidos. Seu } \\
\text { irmão, Jorge Viana, ex- } \\
\text { governador do estado, } \\
\text { foi eleito senador na } \\
\text { mesma data. No banco } \\
\text { de dados do Senado, } \\
\text { constam } 202 \text { processos } \\
\text { relatados por ele. Obs.: } \\
\text { nesse total, estão } \\
\text { inclusos também } \\
\text { processos que apenas } \\
\text { tramitam no Senado, } \\
\text { como os referentes ao } \\
\text { controle do } \\
\text { endividamento público e } \\
\text { à aprovação da } \\
\text { nomeação de } \\
\text { autoridades. }\end{array}$ \\
\hline $\begin{array}{ll}6 & \text { PL 18/2007 } \\
& \text { PL 261/2007 }\end{array}$ & $\begin{array}{l}\text { PL 3.535/ } \\
2008 \text { na } \\
\text { Câmara dos } \\
\text { Deputados }\end{array}$ & $\begin{array}{l}\text { Lei } 12.187 / \\
2009\end{array}$ & $\begin{array}{c}\text { Deputado } \\
\text { Antônio Carlos } \\
\text { Mendes Thame } \\
\text { (PSDB/SP) }\end{array}$ & $\begin{array}{l}\text { - Autor do } \\
\text { Objeto } \\
\text { - Relator do } \\
\text { Objeto }\end{array}$ & $\begin{array}{l}\text { Deputado federal com } \\
\text { seis mandatos, ele } \\
\text { também tem } \\
\text { permanecido em várias } \\
\text { sessões legislativas } \\
\text { como titular da } \\
\text { comissão de meio } \\
\text { ambiente da Câmara. } \\
\text { Professor universitário } \\
\text { da área da agronomia } \\
\text { com base eleitoral em } \\
\text { região sucroalcooleira, } \\
\text { o Deputado Thame } \\
\text { dedica atenção especial } \\
\text { às interfaces entre meio } \\
\text { ambiente e agricultura, } \\
\text { e entre meio ambiente e } \\
\text { energia. Coordena o } \\
\text { grupo de trabalho sobre } \\
\text { energias renováveis da } \\
\text { Frente Parlamentar } \\
\text { Ambientalista. No banco } \\
\text { de dados da Câmara, } \\
\text { constam } 312 \text { projetos } \\
\text { de lei ordinária } \\
\text { apresentados por ele, e } \\
57 \text { processos relatados. }\end{array}$ \\
\hline 7 PL 2.278/2007 & MP 422/2008 & $\begin{array}{l}\text { Lei } 11.763 / \\
2008\end{array}$ & $\begin{array}{c}\text { Deputado } \\
\text { Asdrúbal } \\
\text { Bentes (PMDB/ } \\
\text { PA) }\end{array}$ & $\begin{array}{l}\text { - Autor do } \\
\text { Objeto } \\
\text { - Relator do } \\
\text { Produto }\end{array}$ & $\begin{array}{l}\text { Asdrúbal Bentes é } \\
\text { deputado com seis } \\
\text { mandatos, com atuação } \\
\text { direcionada a assuntos } \\
\text { relacionados à } \\
\text { Amazônia. Advogado, foi } \\
\text { presidente do Grupo } \\
\text { Executivo das Terras do } \\
\text { Araguaia-Tocantins } \\
\text { (Getat) e } \\
\text { superintendente do } \\
\text { Instituto Nacional de } \\
\text { Colonização e Reforma } \\
\text { Agrária (Incra) no Pará, } \\
\text { o que denota }\end{array}$ \\
\hline
\end{tabular}


REVISTA DE SOCIOLOGIA E POLÍTICA V. 21, Nº 48: 19-50 DEZ. 2013

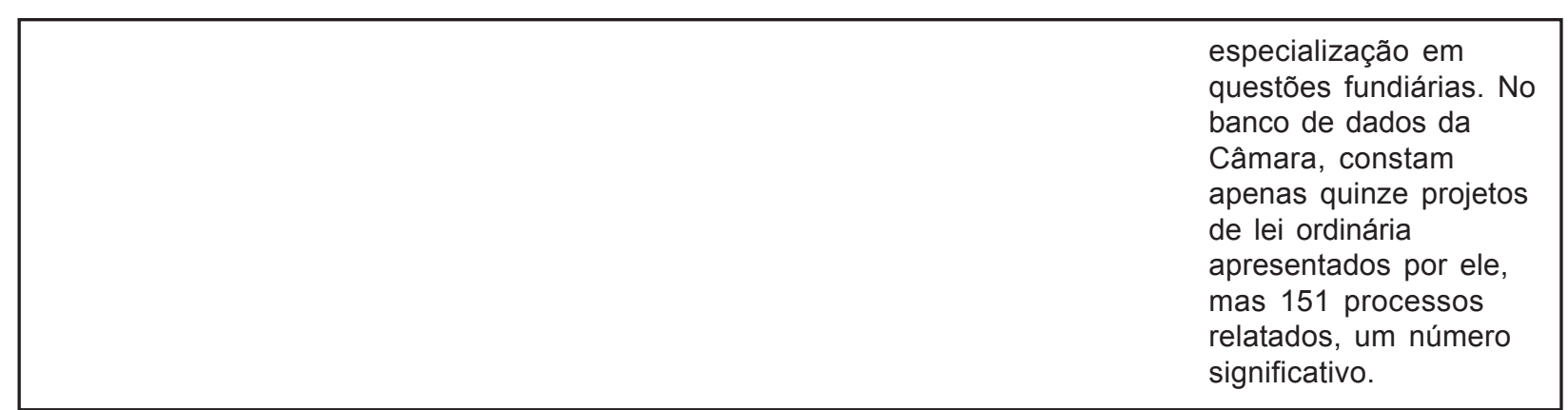

FONTE: Os autores, a partir de dados do Senado Federal e da Câmara dos Deputados.

NOTA: Dados levantados em maio de 2012. 
ANEXO II

COMISSÕES ESPECIAIS DE PROJETOS DE LEI NA CÂMARA DOS DEPUTADOS - 53ª LEGISLATURA (2007-2010)

\begin{tabular}{|c|c|c|c|c|c|c|}
\hline $\begin{array}{l}\text { Comissão } \\
\text { Especial (CE) }\end{array}$ & Coordenação & Período $^{1}$ & Audiências & Participantes & Resultado & Conclusão \\
\hline $\begin{array}{l}1 \text { Salário mínimo } \\
\text { (PL 001/2007) }\end{array}$ & $\begin{array}{c}\text { Rel. Roberto } \\
\text { Santiago (PV/SP); } \\
\text { Pres. Júlio Delgado } \\
\text { (PSB/MG) }\end{array}$ & $\begin{array}{l}\text { 8.mar.2007 a } \\
\text { 11.jun.2008 }\end{array}$ & - & - & $\begin{array}{c}\text { O relator } \\
\text { não } \\
\text { apresentou } \\
\text { parecer e } \\
\text { foi } \\
\text { substituído. } \\
\text { Processo } \\
\text { no } \\
\text { plenário. }\end{array}$ & $\begin{array}{c}\text { rel. anti-agenda } \\
\text { holder }\end{array}$ \\
\hline $\begin{array}{l}2 \text { Informações } \\
\text { detidas pela } \\
\text { Adm. Pública } \\
\text { (PL 219/2003) }\end{array}$ & $\begin{array}{c}\text { Rel. Mendes } \\
\text { Ribeiro Filho } \\
\text { (PMDB/RS); Pres. } \\
\text { José Genoíno (PT/ } \\
\text { SP) }\end{array}$ & $\begin{array}{l}\text { 5.jun.2008 a } \\
\text { 21.out.2009 }\end{array}$ & $\begin{array}{l}4 \text { (articulação } \\
\text { relator/ } \\
\text { presidente } \\
\text { caracterizada) }\end{array}$ & $\begin{array}{l}5 \text { gov., } 3 \text { Judic., } 2 \\
\text { empres., } 2 \text { soc. } \\
\text { civil, } 1 \text { acad., } 2 \\
\text { internacional }\end{array}$ & $\begin{array}{c}\text { Aprovado } \\
\text { substitutivo } \\
\text { do relator. } \\
\text { Plenário. } \\
\text { Lei } 12.527 / \\
2011 .\end{array}$ & $\begin{array}{c}\text { rel. agenda } \\
\text { holder (policy } \\
\text { broker)/ } \\
\text { indicativos de } \\
\text { pres. agenda } \\
\text { holder }\end{array}$ \\
\hline $\begin{array}{l}3 \text { Lei do Gás (PL } \\
334 / 2007 \text { e } \\
\text { apensos) }\end{array}$ & $\begin{array}{l}\text { Rel. João Maia (PR/ } \\
\text { RN); Pres. Max } \\
\text { Rosenmann } \\
\text { (PMDB/PR) }\end{array}$ & $\begin{array}{c}\text { 12.mar.2007 a } \\
\text { 29.ago.2007 }\end{array}$ & $\begin{array}{l}6 \text { (a maior parte } \\
\text { dos nomes } \\
\text { propostos pelo } \\
\text { relator) }\end{array}$ & $\begin{array}{l}2 \text { Leg., } 4 \text { gov., } 3 \\
\text { empres., } 3 \text { soc. } \\
\text { civil }\end{array}$ & $\begin{array}{c}\text { Aprovado } \\
\text { substitutivo } \\
\text { do relator } \\
\text { (ao PL do } \\
\text { Executivo). } \\
\text { Plenário. } \\
\text { Lei } 11.909 / \\
2009 \text {. }\end{array}$ & $\begin{array}{l}\text { rel. agenda } \\
\text { holder (policy } \\
\text { broker) }\end{array}$ \\
\hline $\begin{array}{l}4 \text { Fontes } \\
\text { renováveis de } \\
\text { energia }(P L \\
630 / 20003)\end{array}$ & $\begin{array}{c}\text { Rel. Fernando } \\
\text { Ferro (PT/PE); } \\
\text { Pres. Rodrigo } \\
\text { Rocha Loures } \\
\text { (PMDB/RJ) }\end{array}$ & $\begin{array}{l}\text { 5.jun.2008 a } \\
\text { 21.out.2009 }\end{array}$ & $\begin{array}{l}15 \text { (reg. } \\
\text { incompletos; } \\
\text { assume-se } \\
\text { articulação } \\
\text { relator/ } \\
\text { presidente) }\end{array}$ & $\begin{array}{l}4 \text { Leg., } 10 \text { gov., } 6 \\
\text { empres., } 4 \text { soc. } \\
\text { civil, } 7 \text { acad.,01 } \\
\text { técnico e } 1 \\
\text { internacional }\end{array}$ & $\begin{array}{l}\text { Aprovado } \\
\text { substitutivo. } \\
\text { Aguarda- } \\
\text { se recurso } \\
\text { contra o } \\
\text { poder } \\
\text { conclusivo } \\
\text { daCE. }\end{array}$ & $\begin{array}{l}\text { rel. agenda } \\
\text { holder }\end{array}$ \\
\hline $\begin{array}{l}5 \text { Transporte } \\
\text { coletivo urbano } \\
\text { (PL 694/1995 e } \\
\text { apensos) }\end{array}$ & $\begin{array}{c}\text { Rel. Ângela Amin } \\
\text { (PP/SC); Pres. } \\
\text { Eduardo Sciarra } \\
\text { (PSD/PR) }\end{array}$ & $\begin{array}{l}\text { 17.set.2007 a } \\
\text { 10.mar.2010 }\end{array}$ & $\begin{array}{l}5 \text { (propostas de } \\
\text { "'s } \\
\text { parlamentares, } \\
\text { destaque p/o } \\
\text { presidente) }\end{array}$ & $\begin{array}{c}10 \text { gov., } 2 \\
\text { empres., } 2 \text { soc. } \\
\text { civil e } 1 \text { academia }\end{array}$ & $\begin{array}{c}\text { Aprovado } \\
\text { substitutivo } \\
\text { do relator, } \\
\text { mantido o } \\
\text { poder } \\
\text { conclusivo } \\
\text { da CE. Lei } \\
12.587 / \\
2012 \text {. }\end{array}$ & $\begin{array}{c}\text { rel. agenda } \\
\text { holder (policy } \\
\text { broker)/ } \\
\text { indicativos de } \\
\text { pres. agenda } \\
\text { holder }\end{array}$ \\
\hline $\begin{array}{l}6 \text { Acesso a redes } \\
\text { digitais (PL } \\
1.481 / 2007 \mathrm{e} \\
\text { apensos) }\end{array}$ & $\begin{array}{c}\text { Rel. Paulo } \\
\text { Henrique Lustosa } \\
\text { (PMDB/CE); Pres. } \\
\text { Marcelo Ortiz (PV/ } \\
\text { SP) }\end{array}$ & $\begin{array}{c}\text { 2.abr.2008 a } \\
\text { 18.jun.2008 }\end{array}$ & $\begin{array}{l}5 \text { (a maior parte } \\
\text { dos nomes } \\
\text { propostos pelo } \\
\text { relator) }\end{array}$ & $\begin{array}{l}2 \text { Leg., } 9 \text { gov., } 4 \\
\text { empres. }\end{array}$ & $\begin{array}{l}\text { Aprovado } \\
\text { substitutivo } \\
\text { do relator, } \\
\text { mas se } \\
\text { aguarda o } \\
\text { plenário. }\end{array}$ & $\begin{array}{l}\text { rel. agenda } \\
\text { holder }\end{array}$ \\
\hline $\begin{array}{l}7 \text { Recursos } \\
\text { minerais em } \\
\text { terras indígenas } \\
\text { (PL 1.610/1996 } \\
\text { e apensos) }\end{array}$ & $\begin{array}{c}\text { Rel. Eduardo } \\
\text { Valverde (PT/PR); } \\
\text { Pres. Édio Lopes } \\
\text { (PMDB/RR) }\end{array}$ & $\begin{array}{l}\text { 5.nov.2007 a } \\
\text { 9.jun.2009 }\end{array}$ & $\begin{array}{l}10 \text { (articulação } \\
\text { relator/ } \\
\text { presidente } \\
\text { caracterizada) }\end{array}$ & $\begin{array}{l}6 \text { gov., } 1 \text { Judic., } 2 \\
\text { empres., } 24 \text { soc. } \\
\text { civil (indígenas), } \\
2 \text { acad., } 1 \\
\text { internacional }\end{array}$ & $\begin{array}{c}\text { O relator } \\
\text { apresentou } \\
\text { substitutivo, } \\
\text { não votado } \\
\text { na CE. } \\
\text { Outra CE } \\
\text { na } 54^{a} \text { Leg. }\end{array}$ & $\begin{array}{c}\text { rel. agenda } \\
\text { holderl } \\
\text { indicativos de } \\
\text { pres. agenda } \\
\text { holder }\end{array}$ \\
\hline
\end{tabular}




\begin{tabular}{|c|c|c|c|c|c|c|}
\hline $\begin{array}{l}8 \text { Atendimento } \\
\text { socioeducativo } \\
\text { (PL 1.627/2007) }\end{array}$ & $\begin{array}{c}\text { Rel. Rita Camata } \\
\text { (PSDB/ES); Pres. } \\
\text { Givaldo Carimbão } \\
\text { (PSB/AL) }\end{array}$ & $\begin{array}{l}\text { 24.jun.2008 a } \\
\text { 29.abr.2009 }\end{array}$ & $\begin{array}{c}8 \text { (a maior parte } \\
\text { dos nomes } \\
\text { propostos pela } \\
\text { relatora) }\end{array}$ & $\begin{array}{l}8 \text { gov., } 9 \text { Jud., } 3 \\
\text { soc. civil, } 1 \\
\text { academia, } 1 \\
\text { internacional }\end{array}$ & $\begin{array}{c}\text { Aprovado } \\
\text { substitutivo } \\
\text { da } \\
\text { relatora. } \\
\text { Plenário. } \\
\text { Lei } 12.592 / \\
2012 .\end{array}$ & $\begin{array}{l}\text { rel. agenda } \\
\text { holder (policy } \\
\text { broker, com } \\
\text { consolidação } \\
\text { temática) }\end{array}$ \\
\hline $\begin{array}{l}9 \text { Código Florestal } \\
\text { (PL 1.876/1999 } \\
\text { e apensos) }\end{array}$ & $\begin{array}{c}\text { Rel. Aldo Rebelo } \\
\text { (PCdoB/SP); Pres. } \\
\text { Moacir Micheletto } \\
\text { (PMDB/PR) }\end{array}$ & $\begin{array}{c}\text { 29.set.2009 a } \\
\text { 06.jul.2010 }\end{array}$ & $\begin{array}{l}14 \text { (propostas } \\
\text { de '“s } \\
\text { parlamentares, } \\
\text { destaque p/o } \\
\text { relator). Houve } \\
\text { vários } \\
\text { seminários nos } \\
\text { estados. }\end{array}$ & $\begin{array}{l}15 \text { gov., } 1 \text { Jud., } 3 \\
\text { empres., } 9 \text { soc. } \\
\text { civil, } 7 \text { academia, } \\
1 \text { técnico }\end{array}$ & $\begin{array}{l}\text { Aprovado } \\
\text { substitutivo } \\
\text { do relator. } \\
\text { Aguarda- } \\
\text { se decisão } \\
\text { sobre o } \\
\text { texto do } \\
\text { Senado. }\end{array}$ & $\begin{array}{c}\text { rel. agenda } \\
\text { holder (anti- } \\
\text { policy broker, } \\
\text { pelo } \\
\text { acirramento do } \\
\text { conflito) }\end{array}$ \\
\hline $\begin{array}{c}10 \text { Tarifa social de } \\
\text { energia elétrica } \\
\text { (PL 1.921/1999 } \\
\text { e apensos) }\end{array}$ & $\begin{array}{c}\text { Rel. Carlos } \\
\text { Zarattini (PT/SP); } \\
\text { Pres. Leandro } \\
\text { Sampaio (PPS/RJ) }\end{array}$ & $\begin{array}{c}\text { 18.jun.2007 a } \\
\text { 14.out.2009 }\end{array}$ & $\begin{array}{l}7 \text { (todos os } \\
\text { nomes } \\
\text { propostos pelo } \\
\text { relator) }\end{array}$ & $\begin{array}{l}8 \text { gov., } 1 \text { Jud., } 4 \\
\text { empres., } 4 \text { soc. } \\
\text { civil }\end{array}$ & $\begin{array}{c}\text { Aprovado } \\
\text { substitutivo } \\
\text { do relator. } \\
\text { Lei } 12.212 \text { / } \\
2010 .\end{array}$ & $\begin{array}{l}\text { rel. agenda } \\
\text { holder (policy } \\
\text { broker) }\end{array}$ \\
\hline $\begin{array}{l}11 \text { Desoneração } \\
\text { tributária do } \\
\text { transporte }(\mathrm{PL} \\
1.927 / 2003 \mathrm{e} \\
\text { apensos) }\end{array}$ & $\begin{array}{c}\text { Rel. Carlos } \\
\text { Zarattini (PT/SP); } \\
\text { Pres. Jackson } \\
\text { Barreto (PMDB/SE) }\end{array}$ & $\begin{array}{c}\text { 11.fev.2009 a } \\
\text { 07.out.2009 }\end{array}$ & $\begin{array}{l}7 \text { (reg. } \\
\text { incompletos; } \\
\text { assume-se } \\
\text { articulação } \\
\text { relator/ } \\
\text { presidente) }\end{array}$ & $\begin{array}{c}12 \text { gov., } 5 \\
\text { empres., } 1 \text { soc. } \\
\text { civil }\end{array}$ & $\begin{array}{c}\text { Aprovado } \\
\text { substitutivo } \\
\text { do relator, } \\
\text { mantido o } \\
\text { poder } \\
\text { conclusivo } \\
\text { da CE. } \\
\text { Aguarda- } \\
\text { se retorno } \\
\text { do } \\
\text { Senado. }\end{array}$ & $\begin{array}{l}\text { rel. agenda } \\
\text { holder (policy } \\
\text { broker) }\end{array}$ \\
\hline $\begin{array}{l}12 \text { Execução adm. } \\
\text { da dívida ativa } \\
\text { (PL 2.412/2007 } \\
\text { e apensos) }\end{array}$ & $\begin{array}{c}\text { Rel. João Paulo } \\
\text { Cunha (PT/SP); } \\
\text { Pres. Jurandil } \\
\text { Juarez (PMDB/AP) }\end{array}$ & $\begin{array}{c}\text { 02.fev.2010 a } \\
\text { 24.mar.2010 }\end{array}$ & - & - & $\begin{array}{l}\text { O relator } \\
\text { não } \\
\text { apresentou } \\
\text { parecer. } \\
\text { Aguarda- } \\
\text { se parecer } \\
\text { da CCJC. }\end{array}$ & $\begin{array}{c}\text { rel. anti-agenda } \\
\text { holder }\end{array}$ \\
\hline $\begin{array}{l}13 \text { Pré-Sal/ } \\
\text { exploração e } \\
\text { produção (PL } \\
2.502 / 2007 \text { e } \\
\text { apensos) }\end{array}$ & $\begin{array}{c}\text { Rel. Henrique } \\
\text { Eduardo Alves } \\
\text { (PMDB/RN); Pres. } \\
\text { Arlindo Chinaglia } \\
\text { (PT/SP) }\end{array}$ & $\begin{array}{c}\text { 16.set.2009a } \\
\text { 11.nov.2009 }\end{array}$ & $\begin{array}{c}8 \text { (propostas de } \\
\text { diferentes } \\
\text { parlamentares, } \\
\text { destaque p/o } \\
\text { presidente) }\end{array}$ & $\begin{array}{c}9 \text { gov., } 3 \text { empres., } \\
2 \text { soc. civil, } 2 \\
\text { academia }\end{array}$ & $\begin{array}{c}\text { O } \\
\text { substitutivo } \\
\text { do relator } \\
\text { foi } \\
\text { aproveitado } \\
\text { em projeto } \\
\text { posterior } \\
\text { do } \\
\text { Executivo. }\end{array}$ & $\begin{array}{l}\text { rel. agenda } \\
\text { holder }\end{array}$ \\
\hline $\begin{array}{l}14 \text { Parcelamento } \\
\text { do solo urbano } \\
\text { (PL 3.057/2000 } \\
\text { e apensos) }\end{array}$ & $\begin{array}{c}\text { Rel. Renato Amary } \\
\text { (PMDB/SP); Pres. } \\
\text { Maria do Carmo } \\
\text { Lara (PT/MG) }\end{array}$ & $\begin{array}{l}\text { 01.jun.2007 a } \\
\text { 12.dez.2007 }\end{array}$ & $\begin{array}{l}2 \text { (propostas de } \\
\text { diferentes } \\
\text { parlamentares, } \\
\text { incluindo o rel. e } \\
\text { a presidente). } \\
\text { Houve } \\
\text { audiências na } \\
52^{\mathrm{a}} \text { leg. }\end{array}$ & $\begin{array}{l}3 \text { gov., } 2 \text { Jud., } 4 \\
\text { empres., } 1 \text { soc. } \\
\text { civil, } 1 \text { academia }\end{array}$ & $\begin{array}{c}\text { O } \\
\text { substitutivo } \\
\text { do relator } \\
\text { foi } \\
\text { aprovado } \\
\text { naCE. } \\
\text { Aguarda- } \\
\text { se votação } \\
\text { em } \\
\text { plenário. } \\
\text { Processo } \\
\text { parado. }\end{array}$ & $\begin{array}{l}\text { rel. agenda } \\
\text { holder }\end{array}$ \\
\hline
\end{tabular}




\begin{tabular}{|c|c|c|c|c|c|c|}
\hline $\begin{array}{l}15 \text { Estatuto da } \\
\text { Metrópole (PL } \\
\text { 3.460/2004) }\end{array}$ & $\begin{array}{l}\text { Rel. Índio da Costa } \\
\text { (DEM/RJ); Pres. } \\
\text { Marcelo Melo } \\
\text { (PMDB/GO) }\end{array}$ & $\begin{array}{l}\text { 18.maio.2009a } \\
\text { 01.jul.2009 }\end{array}$ & $\begin{array}{c}3 \text { (reg. } \\
\text { incompletos; } \\
\text { assume-se } \\
\text { articulação } \\
\text { relator/ } \\
\text { presidente) }\end{array}$ & $\begin{array}{l}2 \text { Leg., } 3 \text { gov., } 1 \\
\text { academia }\end{array}$ & $\begin{array}{l}\text { O relator } \\
\text { não } \\
\text { apresentou } \\
\text { parecer. } \\
\text { Outra CE } \\
\text { na 54 } 4^{\mathrm{a}} \mathrm{Leg} .\end{array}$ & $\begin{array}{c}\text { rel. anti-agenda } \\
\text { holder }\end{array}$ \\
\hline $\begin{array}{l}16 \text { Contratos de } \\
\text { seguro privado } \\
\text { (PL } 3.555 / 2004 \\
\text { e apensos) }\end{array}$ & $\begin{array}{c}\text { Rel. Jorginho } \\
\text { Maluly (DEM/SP); } \\
\text { Pres. Moreira } \\
\text { Mendes (PPS/RO) }\end{array}$ & $\begin{array}{l}\text { 05.nov.2009 a } \\
\text { 23.mar.2010 }\end{array}$ & $\begin{array}{l}3 \text { (propostas de } \\
\text { diferentes } \\
\text { parlamentares, } \\
\text { incluindo o rel. e } \\
\text { o presidente). }\end{array}$ & $\begin{array}{l}1 \text { Leg., } 3 \\
\text { empres., } 4 \\
\text { academia. }\end{array}$ & $\begin{array}{c}\text { O relator } \\
\text { não } \\
\text { apresentou } \\
\text { parecer. } \\
\text { Outra CE } \\
\text { na 54ª Leg. }\end{array}$ & $\begin{array}{c}\text { rel. anti-agenda } \\
\text { holder }\end{array}$ \\
\hline $\begin{array}{l}17 \text { CADE e defesa } \\
\text { da concorrência } \\
\text { (PL 3.937/2004 } \\
\text { e apenso) }\end{array}$ & $\begin{array}{l}\text { Rel. Ciro Gomes } \\
\text { (PSB/CE); Pres. } \\
\text { Vignatti (PT/SC) }\end{array}$ & $\begin{array}{l}\text { 20.abr.2007 a } \\
\text { 28.maio.2008 }\end{array}$ & $\begin{array}{c}4 \text { (reg. } \\
\text { incompletos; } \\
\text { assume-se } \\
\text { articulação } \\
\text { relator/ } \\
\text { presidente) }\end{array}$ & $\begin{array}{l}3 \text { gov., } 1 \text { Jud., } 1 \\
\text { empres., } 5 \\
\text { técnicos (ex- } \\
\text { governo) }\end{array}$ & $\begin{array}{c}\text { Aprovado } \\
\text { substitutivo } \\
\text { do relator } \\
\text { (ao PL do } \\
\text { Executivo). } \\
\text { Plenário. } \\
\text { Lei } 12.529 / \\
2011 .\end{array}$ & $\begin{array}{l}\text { rel. agenda } \\
\text { holder (policy } \\
\text { broker) }\end{array}$ \\
\hline $\begin{array}{l}18 \text { Cargos no } \\
\text { BACEN e pesca } \\
\text { (PL 3.960/2008) }\end{array}$ & $\begin{array}{c}\text { Rel. José Airton } \\
\text { Cirilo (PT/CE); } \\
\text { Pres. Flávio } \\
\text { Bezerra (PMDB/ } \\
\text { CE) }\end{array}$ & $\begin{array}{l}\text { 29.set.2008 a } \\
\text { 25.mar.2009 }\end{array}$ & $\begin{array}{l}2 \text { (propostas de } \\
\text { diferentes } \\
\text { parlamentares, } \\
\text { destaque p/o } \\
\text { relator) }\end{array}$ & $\begin{array}{c}3 \text { gov., } 1 \text { empres., } \\
2 \text { soc. civil }\end{array}$ & $\begin{array}{l}\text { Aprovado } \\
\text { parecer do } \\
\text { relator, sem } \\
\text { substitutivo, } \\
\text { mantido o } \\
\text { poder } \\
\text { conclusivo } \\
\text { da CE. Lei } \\
11.958 / \\
2009 \text {. }\end{array}$ & $\begin{array}{l}\text { indicativos de } \\
\text { forte controle } \\
\text { pelo Executivo } \\
\text { (autor), } \\
\text { descaracterizando } \\
\text { o agenda } \\
\text { holder }\end{array}$ \\
\hline $\begin{array}{l}19 \text { Reforma } \\
\quad \text { universitária (PL } \\
4.212 / 2004 \mathrm{e} \\
\text { apensos) }\end{array}$ & $\begin{array}{c}\text { Rel. Jorginho } \\
\text { Maluly (DEM/SP); } \\
\text { Pres. Lelo Coimbra } \\
\text { (PMDB/ES) }\end{array}$ & $\begin{array}{l}\text { 26.mar.2009a } \\
\text { 1.set.2009 }\end{array}$ & $\begin{array}{c}6 \text { (reg. } \\
\text { incompletos; } \\
\text { assume-se } \\
\text { articulação } \\
\text { relator/ } \\
\text { presidente) }\end{array}$ & $\begin{array}{c}3 \text { Leg., } 2 \text { gov., } 4 \\
\text { empres., } 5 \text { soc. } \\
\text { civil, } 6 \text { sociedade } \\
\text { civil }\end{array}$ & $\begin{array}{c}\text { O relator } \\
\text { apresentou } \\
\text { substitutivo, } \\
\text { não votado } \\
\text { naCE. CE } \\
\text { na 54 Leg. } \\
\text { ainda não } \\
\text { criada. }\end{array}$ & $\begin{array}{l}\text { rel. agenda } \\
\text { holder }\end{array}$ \\
\hline $\begin{array}{l}20 \text { Centros de } \\
\text { inclusão digital } \\
(P L 4.361 / 2004)\end{array}$ & $\begin{array}{c}\text { Rel. Otávio Leite } \\
\text { (PSDB/RJ); Pres. } \\
\text { Paulo Teixeira (PT/ } \\
\text { SP) }\end{array}$ & $\begin{array}{l}\text { 16.dez.2009 a } \\
08 . \operatorname{dez} .2010\end{array}$ & $\begin{array}{l}7 \text { (a maior parte } \\
\text { dos nomes } \\
\text { propostos pelo } \\
\text { relator). Houve } \\
\text { também } \\
\text { seminários. }\end{array}$ & $\begin{array}{c}13 \text { gov., } 1 \text { Jud., } 2 \\
\text { empres., } 9 \text { soc. } \\
\text { civil, } 3 \text { academia, } \\
1 \text { mídia }\end{array}$ & $\begin{array}{c}\text { Aprovado } \\
\text { substitutivo } \\
\text { do relator. } \\
\text { Mobilização } \\
\text { política do } \\
\text { presidente. } \\
\text { Aguarda- } \\
\text { se retorno } \\
\text { do Senado. }\end{array}$ & $\begin{array}{c}\text { rel. agenda } \\
\text { holderl } \\
\text { indicativos de } \\
\text { pres. agenda } \\
\text { holder }\end{array}$ \\
\hline $\begin{array}{l}21 \text { Segurança } \\
\text { privada (PL } \\
4.436 / 2008 \text { e } \\
\text { apensos) }\end{array}$ & $\begin{array}{c}\text { Rel. Professor } \\
\text { Sétimo(PMDB/ } \\
\text { MA); Pres. Filipe } \\
\text { Pereira(PSC/RJ) }\end{array}$ & $\begin{array}{c}\text { 27.abr.2009 a } \\
\text { 12.ago.2009 }\end{array}$ & $\begin{array}{c}4 \text { (reg. } \\
\text { incompletos; } \\
\text { assume-se } \\
\text { articulação } \\
\text { relator/ } \\
\text { presidente) }\end{array}$ & $\begin{array}{c}1 \text { gov., } 1 \text { empres., } \\
8 \text { soc. civil }\end{array}$ & $\begin{array}{c}\text { O relator } \\
\text { apresentou } \\
\text { substitutivo, } \\
\text { não votado } \\
\text { na CE. CE } \\
\text { na } 54^{a} \text { Leg. } \\
\text { Obs.: O } \\
\text { processo } \\
\text { inclui } 87 \\
\text { PLs. }\end{array}$ & $\begin{array}{l}\text { rel. agenda } \\
\text { holder }\end{array}$ \\
\hline
\end{tabular}




\begin{tabular}{|c|c|c|c|c|c|c|}
\hline $\begin{array}{l}22 \text { Estatuto da } \\
\text { Juventude (PL } \\
4.529 / 2004 \mathrm{e} \\
\text { apensos) }\end{array}$ & $\begin{array}{c}\text { Rel. Manuela } \\
\text { D'Ávila (PCdoB/ } \\
\text { RS); Pres. Lobbe } \\
\text { Neto (PSDB/SP) }\end{array}$ & $\begin{array}{l}\text { 23.jun.2008 a } \\
\text { 23.nov.2010 }\end{array}$ & $\begin{array}{l}4 \text { (reg. } \\
\text { incompletos; } \\
\text { assume-se } \\
\text { articulação } \\
\text { relator/ } \\
\text { presidente) }\end{array}$ & $\begin{array}{l}7 \text { gov., } 1 \text { empres., } \\
1 \text { soc. civil }\end{array}$ & $\begin{array}{c}\text { Aprovado } \\
\text { substitutivo } \\
\text { da relatora. } \\
\text { Plenário. } \\
\text { Aguarda- } \\
\text { se retorno } \\
\text { do Senado. }\end{array}$ & $\begin{array}{c}\text { rel. agenda } \\
\text { holder (cl } \\
\text { concentração } \\
\text { nos entes } \\
\text { governamentais } \\
\text { e esforço de } \\
\text { consolidação } \\
\text { temática) }\end{array}$ \\
\hline $\begin{array}{l}23 \text { Altera a Lei Pelé } \\
\text { (PL 5.186/2005 } \\
\text { e apensos) }\end{array}$ & $\begin{array}{l}\text { Rel. José Rocha } \\
\text { (PR/BA); Pres. } \\
\text { Marcelo } \\
\text { Guimarães Filho } \\
\text { (PMDB/BA) }\end{array}$ & $\begin{array}{c}\text { 24.jun.2008 a } \\
\text { 15.abr.2009 }\end{array}$ & $\begin{array}{l}4 \text { (articulação } \\
\text { relator/ } \\
\text { presidente } \\
\text { caracterizada) }\end{array}$ & $\begin{array}{c}1 \text { gov., } 4 \text { empres., } \\
5 \text { soc. civil, } 1 \\
\text { técnico }\end{array}$ & $\begin{array}{l}\text { Aprovado } \\
\text { substitutivo } \\
\text { do rel. } \\
\text { Aguarda- } \\
\text { se decisão } \\
\text { sobre o } \\
\text { texto do } \\
\text { Senado. }\end{array}$ & $\begin{array}{c}\text { rel. agenda } \\
\text { holderl } \\
\text { indicativos de } \\
\text { pres. agenda } \\
\text { holder }\end{array}$ \\
\hline $\begin{array}{l}24 \text { Pré-Sal/Fundo } \\
\text { Social (PL } \\
5.417 / 2009 \text { e } \\
\text { apenso) }\end{array}$ & $\begin{array}{c}\text { Rel. Antônio } \\
\text { Palocci (PT/SP); } \\
\text { Pres. Rodrigo } \\
\text { Rollemberg (PSB/ } \\
\text { DF) }\end{array}$ & $\begin{array}{c}\text { 16.set.2009a } \\
04 . \text { nov.2009 }\end{array}$ & $\begin{array}{l}4 \text { (a maior parte } \\
\text { dos nomes } \\
\text { propostos pelo } \\
\text { relator) }\end{array}$ & $\begin{array}{l}8 \text { gov., } 1 \text { soc. } \\
\text { civil, } 2 \text { técnicos }\end{array}$ & $\begin{array}{c}\text { Urgência } \\
\text { urgentíssima, } \\
\text { c/ parecer } \\
\text { em } \\
\text { plenário. } \\
\text { Aprovado } \\
\text { substitutivo } \\
\text { do rel. (ao } \\
\text { PL do } \\
\text { Executivo). } \\
\text { Lei 12.351/ } \\
2010 .\end{array}$ & $\begin{array}{l}\text { rel. agenda } \\
\text { holder }\end{array}$ \\
\hline $\begin{array}{l}25 \text { Pré-Sal/PETRO- } \\
\text { SAL (PL 5.939/ } \\
\text { 2009) }\end{array}$ & $\begin{array}{l}\text { Rel. Luiz Fernando } \\
\text { Faria (PP/MG); } \\
\text { Pres. Brizola Neto } \\
\text { (PDT/RJ) }\end{array}$ & $\begin{array}{l}\text { 16.set.2009a } \\
\text { 04.nov.2009 }\end{array}$ & $\begin{array}{l}2 \text { (propostas do } \\
\text { relator e de uma } \\
\text { parlamentar), } \\
\text { ouvida apenas } \\
\text { uma pequena } \\
\text { parcela dos } \\
\text { nomes }\end{array}$ & $\begin{array}{c}1 \text { gov., } 1 \text { empres., } \\
1 \text { soc. civil }\end{array}$ & $\begin{array}{c}\text { Parecer } \\
\text { favorável, } \\
\text { com } \\
\text { algumas } \\
\text { emendas, } \\
\text { aprovado. } \\
\text { Lei } 12.304 / \\
2010 .\end{array}$ & $\begin{array}{c}\text { indicativos de } \\
\text { forte controle } \\
\text { pelo Executivo } \\
\text { (autor), } \\
\text { descaracterizando } \\
\text { o agenda holder }\end{array}$ \\
\hline $\begin{array}{l}26 \text { Pré-Sal/ } \\
\text { Petrobrás (PL } \\
5.941 / 2009)\end{array}$ & $\begin{array}{l}\text { Rel. João Maia } \\
\text { (PR/RN); Pres. } \\
\text { Arnaldo Jardim } \\
\text { (PPS/SP) }\end{array}$ & $\begin{array}{l}\text { 16.set.2009 a } \\
\text { 11.nov.2009 }\end{array}$ & $\begin{array}{l}6 \text { (propostas de } \\
\text { diferentes } \\
\text { parlamentares, } \\
\text { incluindo o } \\
\text { relator). }\end{array}$ & $\begin{array}{c}6 \text { gov., } 2 \text { empres., } \\
3 \text { soc. civil, } 1 \\
\text { técnico }\end{array}$ & $\begin{array}{c}\text { Aprovado } \\
\text { substitutivo } \\
\text { do relator. } \\
\text { Plenário. } \\
\text { Lei } 12.276 / \\
2010 .\end{array}$ & $\begin{array}{l}\text { rel. agenda } \\
\text { holder (policy } \\
\text { broker) }\end{array}$ \\
\hline $\begin{array}{l}27 \text { Estatuto da } \\
\text { lgualdade Racial } \\
\text { (PL 6.264/2005 } \\
\text { e apensos) }\end{array}$ & $\begin{array}{c}\text { Rel. Antônio } \\
\text { Roberto (PV/MG); } \\
\text { Pres. Carlos } \\
\text { Santana (PT/RJ) }\end{array}$ & $\begin{array}{c}\text { 10.mar.2008 a } \\
09 . \text { set.2009 }\end{array}$ & $\begin{array}{l}5 \text { (propostas de } \\
\text { diferentes } \\
\text { parlamentares, } \\
\text { destaque p/o } \\
\text { relator) }\end{array}$ & $\begin{array}{l}1 \text { Leg., } 4 \text { gov., } 1 \\
\text { Jud., } 4 \text { soc. civil, } \\
1 \text { academia }\end{array}$ & $\begin{array}{c}\text { Aprovado } \\
\text { substitutivo } \\
\text { do relator, } \\
\text { mantido o } \\
\text { poder } \\
\text { conclusivo } \\
\text { da CE. Lei } \\
12.288 / \\
2010 \text {. }\end{array}$ & $\begin{array}{l}\text { rel. agenda } \\
\text { holder (policy } \\
\text { broker) }\end{array}$ \\
\hline $\begin{array}{l}28 \text { Organização da } \\
\text { polícia federal } \\
\text { (PL 6.493/2009) }\end{array}$ & $\begin{array}{c}\text { Rel. Laerte Bessa } \\
\text { (PSC/DF); Pres. } \\
\text { Nelson Pellegrino } \\
\text { (PT/BA) }\end{array}$ & $\begin{array}{l}\text { 6.abr.2010a } \\
\text { 8.jun.2010 }\end{array}$ & $\begin{array}{l}8 \text { (propostas de } \\
\text { um parlamentar } \\
\text { específico, mas } \\
\text { com indicação } \\
\text { de negociação } \\
\text { c/o relator) }\end{array}$ & $\begin{array}{c}3 \text { gov., } 29 \text { soc. } \\
\text { civil } \\
\text { (associações } \\
\text { trabalhistas) }\end{array}$ & $\begin{array}{c}\text { O relator } \\
\text { apresentou } \\
\text { substitutivo, } \\
\text { não votado } \\
\text { em razão } \\
\text { do final da } \\
\text { legislatura. } \\
\text { CE na 54a } \\
\text { Leg. }\end{array}$ & $\begin{array}{l}\text { rel. agenda } \\
\text { holder }\end{array}$ \\
\hline
\end{tabular}




\begin{tabular}{|c|c|c|c|c|c|c|}
\hline $\begin{array}{l}29 \text { Código Bras. } \\
\text { Aeronáutica (PL } \\
6.716 / 2009 \text { e } \\
\text { apensos) }\end{array}$ & $\begin{array}{c}\text { Rel. Rodrigo } \\
\text { Rocha Loures } \\
\text { (PMDB/PR); Pres. } \\
\text { Luiz Sérgio (PT/ } \\
\text { MG) }\end{array}$ & $\begin{array}{l}\text { 11.mar.2009a } \\
\text { 23.jun.2010 }\end{array}$ & $\begin{array}{c}8 \text { (reg. } \\
\text { incompletos; } \\
\text { assume-se } \\
\text { articulação } \\
\text { relator/ } \\
\text { presidente) }\end{array}$ & $\begin{array}{c}13 \text { gov., } 12 \\
\text { empres., } 4 \text { soc. } \\
\text { civil, } 1 \text { academia }\end{array}$ & $\begin{array}{c}\text { O } \\
\text { substitutivo } \\
\text { do relator } \\
\text { foi } \\
\text { aprovado } \\
\text { na CE. } \\
\text { Aguarda- } \\
\text { se votação } \\
\text { em } \\
\text { plenário. }\end{array}$ & $\begin{array}{l}\text { rel. agenda } \\
\text { holder }\end{array}$ \\
\hline $\begin{array}{l}30 \text { Sistema único } \\
\text { de consórcios } \\
\text { (PL 7.161/2006) }\end{array}$ & $\begin{array}{c}\text { Rel. Alex Canziani } \\
\text { (PTB/PR); Pres. } \\
\text { Aelton Freitas (PR/ } \\
\text { MG) }\end{array}$ & $\begin{array}{l}\text { 18.jun.2007 a } \\
\text { 13.maio.2008 }\end{array}$ & - & - & $\begin{array}{c}\text { Parecer } \\
\text { favorável, } \\
\text { com duas } \\
\text { emendas, } \\
\text { aprovado. } \\
\text { Lei 11.795/ } \\
2008 .\end{array}$ & $\begin{array}{c}\text { rel. anti-agenda } \\
\text { holder }\end{array}$ \\
\hline $\begin{array}{l}31 \text { Empregos } \\
\text { públicos na } \\
\text { FUNASA(PL } \\
7.495 / 2006 \text { e } \\
\text { apensos) }\end{array}$ & $\begin{array}{c}\text { Rel. Domingos } \\
\text { Dutra (PT/MA); } \\
\text { Pres. Benjamin } \\
\text { Maranhão(PMDB/ } \\
\text { PB) }\end{array}$ & $\begin{array}{c}\text { 5.maio. } 2010 \text { a } \\
\text { 4.out.2011 }\end{array}$ & $\begin{array}{l}2 \text { (propostas de } \\
\text { diferentes } \\
\text { parlamentares) }\end{array}$ & 4 gov., 5 soc. civil & $\begin{array}{c}\text { O relator } \\
\text { formulou } \\
\text { substitutivo, } \\
\text { aprovado } \\
\text { pela CE na } \\
54^{\mathrm{a}} \text { Leg. } \\
\text { Aguarda- } \\
\text { se plenário. }\end{array}$ & $\begin{array}{l}\text { rel. agenda } \\
\text { holder }\end{array}$ \\
\hline $\begin{array}{l}32 \text { Licitações e } \\
\quad \text { contratos (PL } \\
7.709 / 2007 \mathrm{e} \\
\text { apensos) }\end{array}$ & $\begin{array}{c}\text { Rel. Márcio } \\
\text { Reinaldo Moreira } \\
\text { (PP/MG); Pres. } \\
\text { Tadeu Filippelli } \\
\text { (PMDB/DF) }\end{array}$ & $\begin{array}{l}\text { 6.mar.2007 a } \\
\text { 25.abr.2007 }\end{array}$ & $\begin{array}{c}7 \text { (reg. } \\
\text { incompletos; } \\
\text { assume-se } \\
\text { articulação } \\
\text { relator/ } \\
\text { presidente) }\end{array}$ & $\begin{array}{c}12 \text { gov., } 4 \\
\text { empres., } 2 \text { soc. } \\
\text { civil }\end{array}$ & $\begin{array}{c}\text { O relator } \\
\text { apresentou } \\
\text { substitutivo, } \\
\text { que foi } \\
\text { votado } \\
\text { diretamente } \\
\text { em } \\
\text { plenário. } \\
\text { Aguarda- } \\
\text { se retorno } \\
\text { do Senado. }\end{array}$ & $\begin{array}{c}\text { rel. agenda } \\
\text { holder }\end{array}$ \\
\hline $\begin{array}{l}33 \text { Limite de } \\
\text { despesa c/ } \\
\text { pessoal (PLP } \\
\text { 001/2007) }\end{array}$ & $\begin{array}{l}\text { Rel. José Pimentel } \\
\text { (PT/CE); Pres. } \\
\text { Nelson Meurer } \\
\text { (PP/PR) }\end{array}$ & $\begin{array}{l}\text { 7.mar.2007a } \\
\text { (?)11 }\end{array}$ & $\begin{array}{l}4 \text { (a maior parte } \\
\text { dos nomes } \\
\text { propostos pelo } \\
\text { relator) }\end{array}$ & $\begin{array}{l}1 \text { Leg., } 2 \text { Jud., } 5 \\
\text { soc. civil, } 1 \\
\text { técnico }\end{array}$ & $\begin{array}{l}\text { O relator } \\
\text { não } \\
\text { apresentou } \\
\text { parecer. CE } \\
\text { na } 54^{\mathrm{a}} \text { Leg. } \\
\text { ainda não } \\
\text { criada. } \\
\text { Processo } \\
\text { parado. }\end{array}$ & $\begin{array}{c}\text { indicativos de } \\
\text { forte controle } \\
\text { pelo Executivo } \\
\text { (autor) sobre a } \\
\text { não-decisão, } \\
\text { descaracterizando } \\
\text { o agenda holder }\end{array}$ \\
\hline
\end{tabular}

FONTE: Os autores, a partir de dados da Câmara dos Deputados.

\section{NOTAS:}

1. Considera-se a data de constituição e a última reunião da comissão especial registrada no sistema da Câmara dos Deputados.

2. Data da última reunião não identificada 


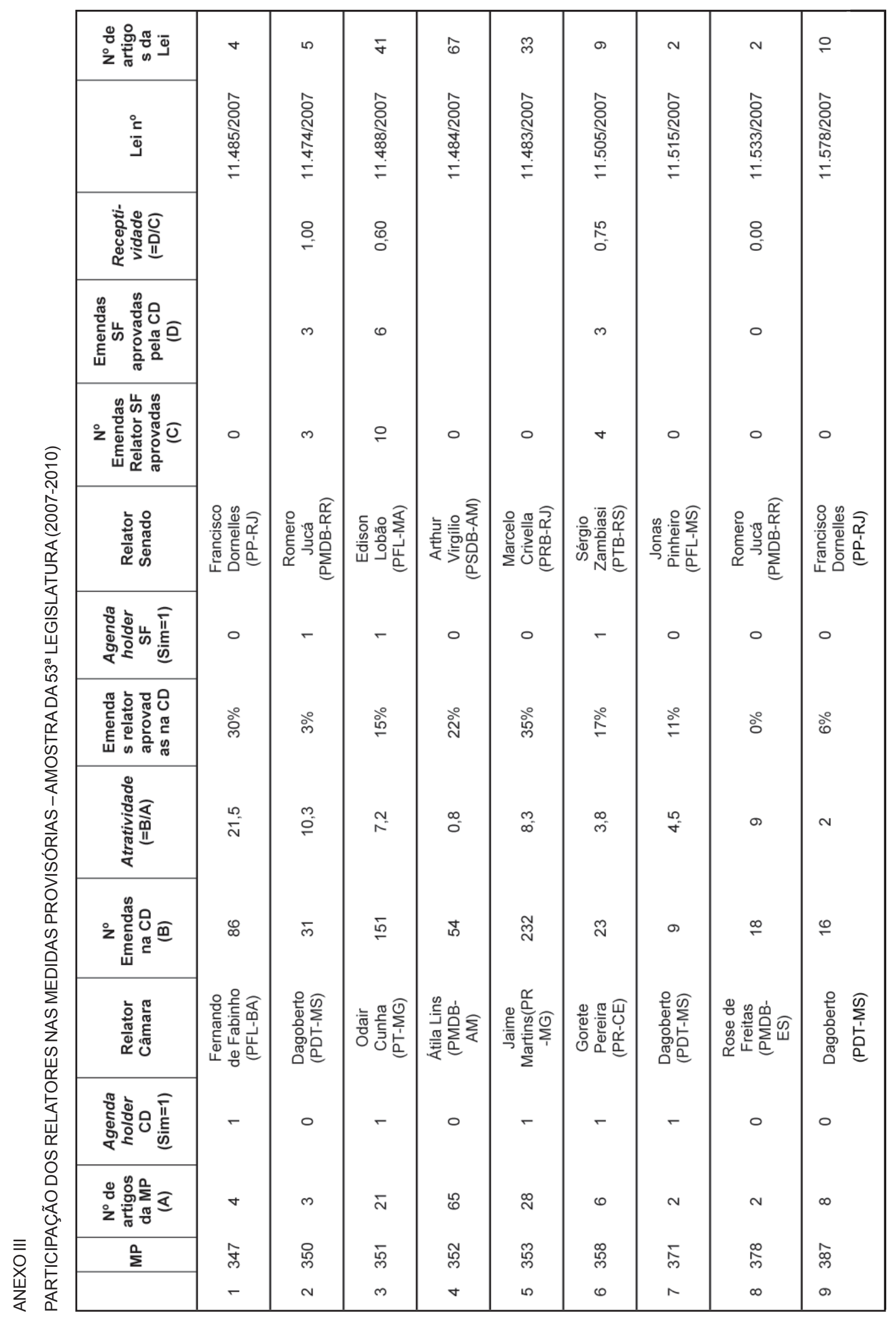




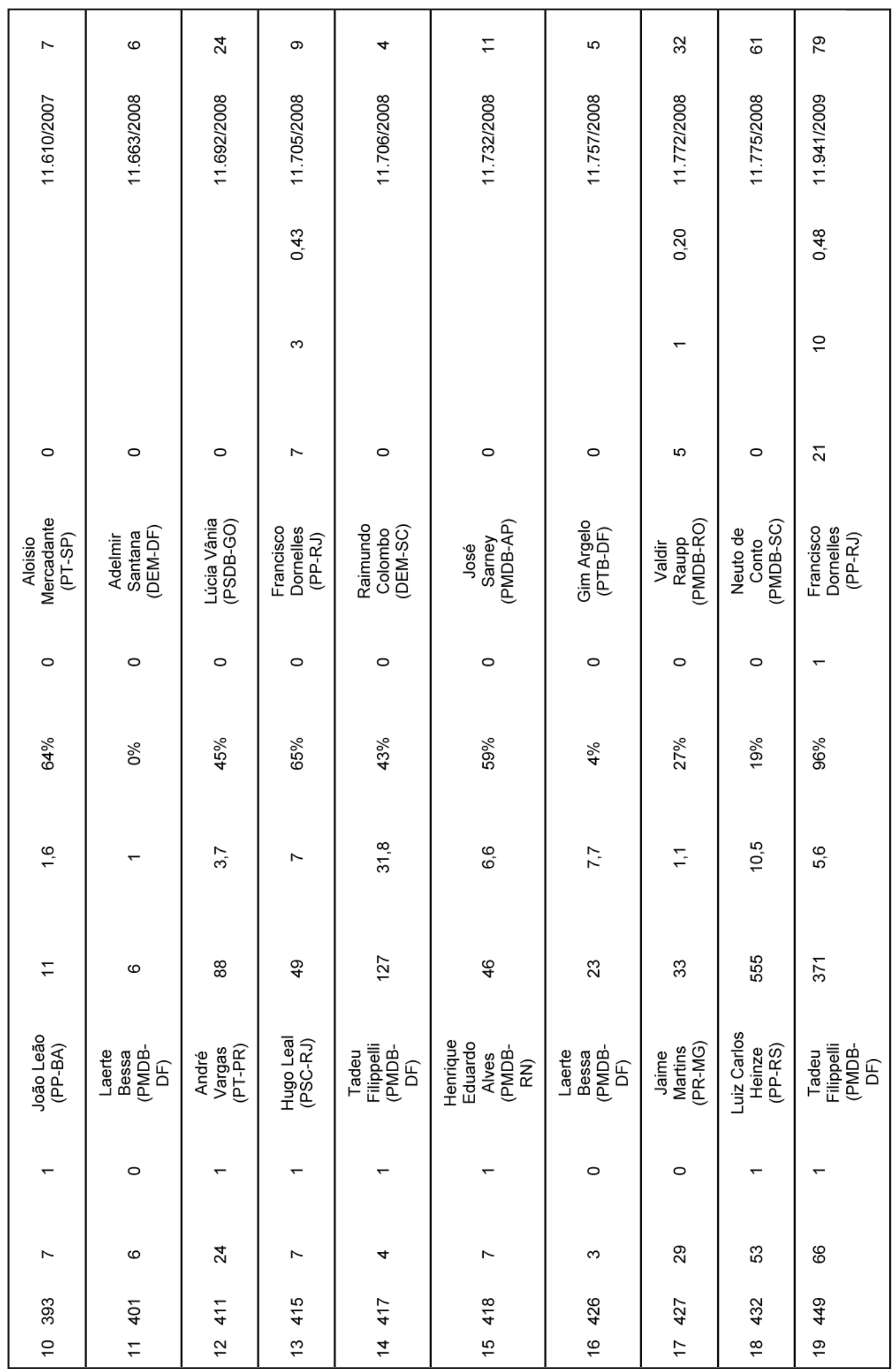




\begin{tabular}{|c|c|c|c|c|c|c|c|c|c|c|}
\hline ம & 으 & $\mathscr{\infty}_{\infty}$ & స్ల & $\stackrel{\infty}{\sim}$ & $\infty$ & $\checkmark$ & $\mathscr{F}$ & $\stackrel{\text { I }}{\Gamma}$ & $\stackrel{m}{\longrightarrow}$ & 으 \\
\hline 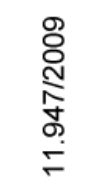 & 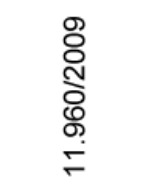 & $\begin{array}{l}\stackrel{8}{0} \\
\text { N } \\
\text { م̦ } \\
\stackrel{\circ}{\leftarrow}\end{array}$ & 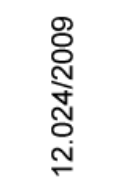 & 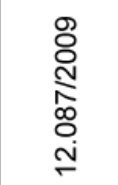 & 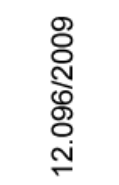 & $\begin{array}{l}\stackrel{ }{\grave{N}} \\
\stackrel{\infty}{N} \\
\stackrel{N}{N}\end{array}$ & 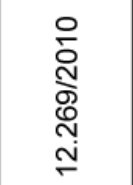 & $\begin{array}{l}\text { 옿 } \\
\text { ờ } \\
\text { ̦. }\end{array}$ & 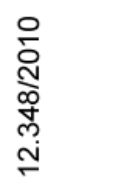 & 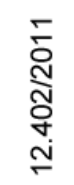 \\
\hline & $\begin{array}{l}\mathscr{\infty} \\
\infty \\
0\end{array}$ & & $\begin{array}{l}\bar{N} \\
0\end{array}$ & $\underset{-}{\stackrel{-}{\circ}}$ & $\underset{-}{\stackrel{8}{r}}$ & & & & & \\
\hline & 으 & & م & 0 & $m$ & & & & & \\
\hline 0 & $\stackrel{ }{\sim}$ & 0 & $\wedge$ & $\sigma$ & $m$ & 0 & o & ○ & o & 0 \\
\hline 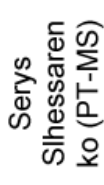 & 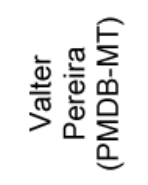 & 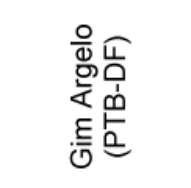 & 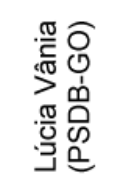 & 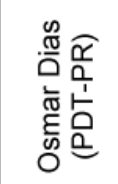 & 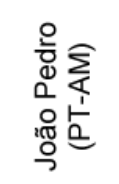 & 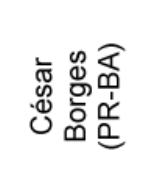 & 웛 & 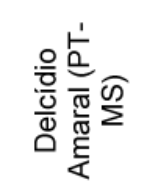 & 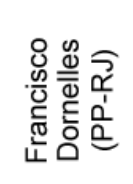 & 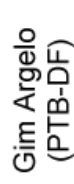 \\
\hline 0 & - & ○ & - & - & - & 0 & 0 & o & 0 & o \\
\hline ळ & 今ે & ळे & ণัণ & ঃे & 。ें & ঃे & ڤ్లે & ઠ̊ & ઠ̊ & ○ें \\
\hline$\stackrel{\leftrightarrow}{\sim}$ & $\hat{i}$ & $\stackrel{\Phi}{m^{\prime}}$ & $\begin{array}{l}\circ \\
\stackrel{0}{\circ}\end{array}$ & $\bar{N}$ & $\stackrel{\nabla}{m}$ & 응 & m & $\dot{0}$ & $\checkmark$ & - \\
\hline 8 & ০ & 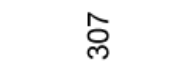 & $\stackrel{\varphi}{\sim}$ & $\hat{N}$ & $\hat{N}$ & o & సิ & $r$ & กิ & م \\
\hline 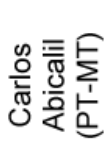 & 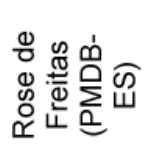 & 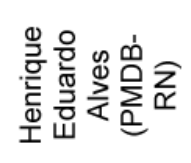 & 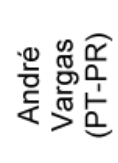 & 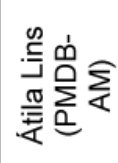 & 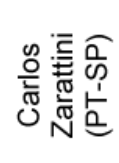 & Ð & 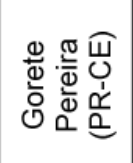 & 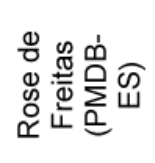 & 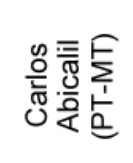 & 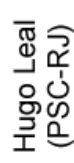 \\
\hline - & - & - & - & - & - & o & - & 0 & 0 & 0 \\
\hline స్ల & $m$ & $\stackrel{R}{R}$ & r & $\stackrel{m}{\longrightarrow}$ & $\infty$ & $\nabla$ & $\stackrel{\infty}{~}$ & $\stackrel{\rho}{\circ}$ & $\stackrel{m}{\check{m}}$ & م \\
\hline 号 & bे & 多 & \&্ণ & ষ্ণ & ஜூ & $\underset{f}{\delta}$ & $\underset{⿱}{\sim}$ & 寄 & ஜ & 음 \\
\hline ণ & $\bar{N}$ & N & N & $\stackrel{\sim}{N}$ & $\stackrel{2}{N}$ & $\stackrel{\sim}{N}$ & $\hat{N}$ & $\stackrel{\infty}{N}$ & D & ి্ల \\
\hline
\end{tabular}




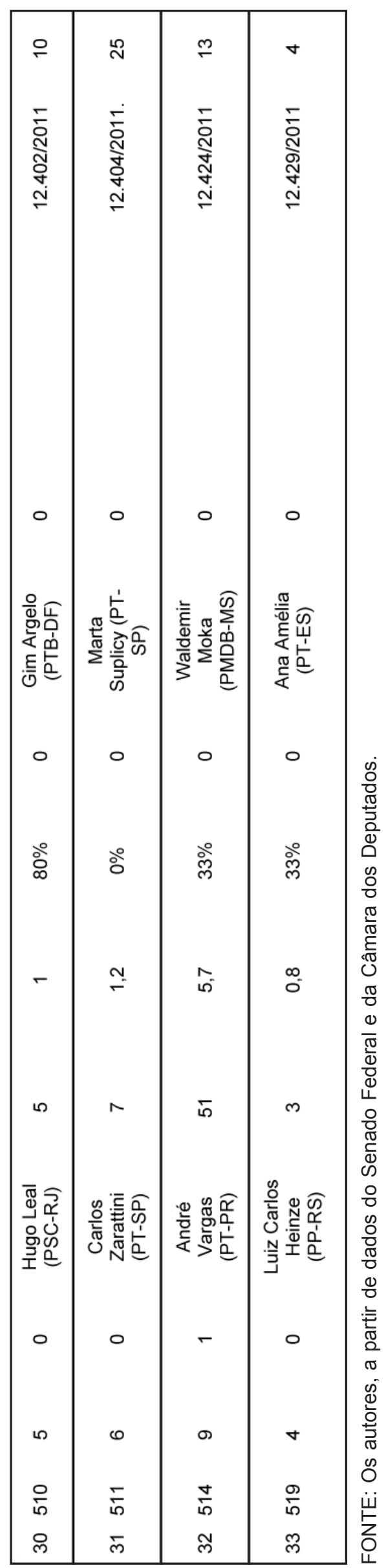




\section{STILL WORTH LEGISLATING: SEEKING THE AGENDA HOLDERS IN CONGRESS.}

\section{Rafael Silveira e Silva e Suely Mara Vaz Guimarães de Araújo}

This paper analyzes the performance strategy of parliamentarians engaged and stand out at political articulation in the arena of law production, called agenda holders. The objective is to present analytical frameworks and the design of this concept in the context of Legislative Studies, and to propose methodological strategies for the observation and analysis of these political actors in Brazilian Congress. Three different approaches have been employed in this work, each one formulated in order to select cases that parlamentarians were protagonists in legislative processes. We analyzed several examples, between the years 2007 and 2011, involving the phenomenon of Appropriation of the legislative agenda, legislative procedures performed through special committees in the House of Representatives and the participation of the rapporteurs in the handling of provisional decrees ("medidas provisórias"). Such methodological approaches have been successful, resulting in interesting observations about the shared requirements for the performance of a parliamentarian as agenda holder, such as past experience and expertise, the seniority in Congress and his or her negotiating skills. The analysis also allowed to observe a consistent link between taking the condition of an agenda holder and political survival as well as the differences in performance between Deputies and Senators. Furthermore, it was possible to verify the existence of parliamentarians who can take, according to some circumstances, the role of anti-agenda holders. It is understood that studying the behavior of agenda holders can enrich analysis that address the actions of the legislature, emphasizing also the need for a more accurate view of the dynamics of the relationship between the Congress and the Executive Branch. In addition, this paper explores through a different prism the building of political careers, adding relevance to the actions of legislators in the legislative process, despite all the difficulties and limitations within the Brazilian political system. Thus, it also rescues the place of parliamentarians in shaping the legislative agenda and formulating laws.

KEYWORDS: agenda holders; parliamentarian; political career; Congress; methodology. 